\title{
Cadmium Uptake, MT Gene Activation and Structure of Large-Sized Multi-Domain Metallothioneins in the Terrestrial Door Snail Alinda biplicata (Gastropoda, Clausiliidae)
}

\author{
Veronika Pedrini-Martha *(D), Simon Köll, Martin Dvorak and Reinhard Dallinger * \\ Department of Zoology and Center of Molecular Biosciences Innsbruck, University of Innsbruck, Technikerstraße \\ 25, 6020 Innsbruck, Austria; Simon.Koell@student.uibk.ac.at (S.K.); martin.dvorak@uibk.ac.at (M.D.) \\ * Correspondence: Veronika.Pedrini-Martha@uibk.ac.at (V.P.-M.); reinhard.dallinger@uibk.ac.at (R.D.)
}

Received: 6 February 2020; Accepted: 24 February 2020; Published: 27 February 2020

check for updates

\begin{abstract}
Terrestrial snails (Gastropoda) possess Cd-selective metallothioneins (CdMTs) that inactivate $\mathrm{Cd}^{2+}$ with high affinity. Most of these MTs are small Cysteine-rich proteins that bind $6 \mathrm{Cd}^{2+}$ equivalents within two distinct metal-binding domains, with a binding stoichiometry of $3 \mathrm{Cd}^{2+}$ ions per domain. Recently, unusually large, so-called multi-domain MTs (md-MTs) were discovered in the terrestrial door snail Alinda biplicata (A.b.). The aim of this study is to evaluate the ability of A.b. to cope with $\mathrm{Cd}$ stress and the potential involvement of md-MTs in its detoxification. Snails were exposed to increasing $\mathrm{Cd}$ concentrations, and Cd-tissue concentrations were quantified. The gene structure of two $m d-M T s$ ( $9 m d-M T$ and 10md-MT) was characterized, and the impact of Cd exposure on $M T$ gene transcription was quantified via qRT PCR. A.b. efficiently accumulates $\mathrm{Cd}$ at moderately elevated concentrations in the feed, but avoids food uptake at excessively high $\mathrm{Cd}$ levels. The structure and expression of the long $m d-M T$ genes of $A . b$. were characterized. Although both genes are intronless, they are still transcribed, being significantly upregulated upon $\mathrm{Cd}$ exposure. Overall, our results contribute new knowledge regarding the metal handling of Alinda biplicata in particular, and the potential role of md-MTs in Cd detoxification of terrestrial snails, in general.
\end{abstract}

Keywords: multi-domain metallothionein; cadmium metabolism; RNA expression; intronless genes; Alinda biplicata; Gastropoda; avoidance behavior

\section{Introduction}

Gastropods represent the most species-rich class within the phylum of Mollusca. Throughout evolution, some gastropod lineages left their marine realms and colonized limnic and terrestrial habitats. The common door snail, Alinda biplicata (family of Clausiliidae), belongs to the gastropod clade of Stylommatophora that has successfully adapted to a terrestrial lifestyle. A. biplicata is widely distributed in central Europe and can be found in forests, between rocks in urban areas (e.g., parks) or at riverside banks [1]. It is one of the rare ovoviviparous snail species in which the whole embryonic development takes place inside the egg within the reproductive tract of the adult individual [2]. The completion of the shell growth of hatched juvenile snails needs 20 to 28 weeks. Subsequently, it takes another 24 to 36 weeks until readily grown snails finish maturation and start to reproduce [2]. To ensure its survival under harsh and sometimes rapidly changing environmental conditions, A. biplicata relies on innate protective stress response mechanisms. For example, a proven strategy to overcome potentially stressful periods is its ability to switch to a state of inactivity, the so-called aestivation [3,4]. Another protective feature of terrestrial snails is their ability to highly accumulate and inactivate toxic metal ions such as Cadmium (Cd) in their digestive organs and cells $[5,6]$. 
One of the most important physiological protection mechanisms involved in metal accumulation and detoxification of snails is the expression of metal-binding proteins of the metallothionein (MT) family [6-8]. MTs are cysteine-rich, metal-binding proteins primarily responsible for cellular metal homeostasis and detoxification [9-11]. MTs may also be involved in protection against oxidative stress [12] and, more generally, in stress response reactions [13-16]. Mono- and divalent metal ions such as $\mathrm{Zn}^{2+}, \mathrm{Cd}^{2+}$, or $\mathrm{Cu}^{+}$are bound by MTs through the sulfhydryl groups of cysteines arranged in highly conserved Cys-Xaa-Cys motifs, building firm metal thiolate clusters [17]. As a particular feature, many snail species express metal-selective MT variants and isoforms derived from metal-unspecific precursors in basal gastropod ancestors $[18,19]$. Metal-selective snail MTs were first discovered in the helicid snails Helix pomatia and Cornu aspersum. Typically, these MTs not only exhibit a metal-selective binding behavior but are also characterized by their distinct cellular expression patterns and physiological functions directly related to the selectively bound metal ion [6,20-22]. For example, Cu-selective MT isoforms (CuMT) of snails preferentially bind monovalent $\mathrm{Cu}$ ions, being expressed in a particular cell type called rhogocyte, involved in $\mathrm{Cu}$ homeostasis and hemocyanin turnover [21,23]. A second, Cd-selective MT isoform (CdMT) binds $\mathrm{Cd}^{2+}$ with high affinity and is devoted to Cd-detoxification and stress response $[7,20]$. In addition, a third, non-metal-selective MT isoform (Cd/CuMT) is able to bind both metal ions simultaneously [6,24], being involved in embryonic snail development [22]. Most snail MTs are structurally organized in two metal-binding domains ( $\mathrm{N}$ - and C-terminal) connected through a short linker region, exhibiting a binding stoichiometry of six divalent $\left(\mathrm{Cd}^{2+}, \mathrm{Zn}^{2+}\right)$ or twelve monovalent $\left(\mathrm{Cu}^{+}\right)$metal ions $[23,25]$. More recent studies demonstrate, however, a greater variability of gastropod MT protein structures than so far known. The marine periwinkle Littorina littorea and its terrestrial relative Pomatias elegans, for example, have increased the metal-binding capacity of their Cd-selective MTs by addition of a third Cd-binding domain, derived from a duplication of their $\mathrm{N}$-terminal domain $[26,27]$. Consequently, these newly discovered three-domain MTs have increased their binding stoichiometry from 6 to $9 \mathrm{Cd}^{2+}$ ions $[26,28]$. Our most recent studies indicate the presence of multi-domain MTs (md-MTs) with as much as eight (8) metal-binding domains (8md-MT) in an MT of the freshwater snail Marisa cornuarietis, and with nine (9) or even ten (10) metal-binding domains (9md-MT and 10md-MT) in two MT isoforms of the terrestrial snail A. biplicata [19]. Following the findings of increased Cd-binding capacities in the three-domain MTs of Littorina littorea and Pomatias elegans (see above), we suggest that the additional multiplication of $\mathrm{N}$-terminal metal-binding domains in the MTs of Marisa cornuarietis and A. biplicata might increase their metal ion stoichiometry and hence, their metal-binding capacity to a correspondingly high level. These new findings remind of molecular evolutionary mechanisms in other species such as Drosophila melanogaster, where an increased Cd resistance in some populations has been achieved by MT gene duplication events [29].

In the present study, we will explore how the terrestrial snail A. biplicata can cope with $\mathrm{Cd}$ stress and which mechanisms might be involved in this process. In particular, we will focus on the transcriptional activation of $9 m d-M T, 10 m d-M T$, and of an additional two-domain CuMT gene of this snail and their potential role in $\mathrm{Cd}$ accumulation and detoxification. Therefore, adult individuals of A. biplicata were exposed to $\mathrm{Cd}$ in the laboratory. First, the MT gene structure of the large $9 m d-M T$ and 10md-MT isoforms was characterized and analyzed for the first time. In addition, multiple parameters such as the feeding behavior of metal-exposed snails, their $\mathrm{Cd}$ tissue accumulation, and the transcriptional upregulation of the two multi-domain MT genes (9md-MT and 10md-MT) and the CuMT gene were quantified and evaluated.

\section{Results and Discussion}

\subsection{Cd Accumulation in Alinda biplicata Is Restrained beyond a High Threshold Level}

After a short-term accumulation period of 4 days, a dose-dependent $\mathrm{Cd}$ accumulation was observed in the soft-tissues of $A$. biplicata up to an exposure concentration of $2692.6 \mu \mathrm{g} / \mathrm{g} \mathrm{d} . \mathrm{w}$. Cd in the food (Cd100), but the accumulation did not further increase beyond this threshold (Figure 1). 

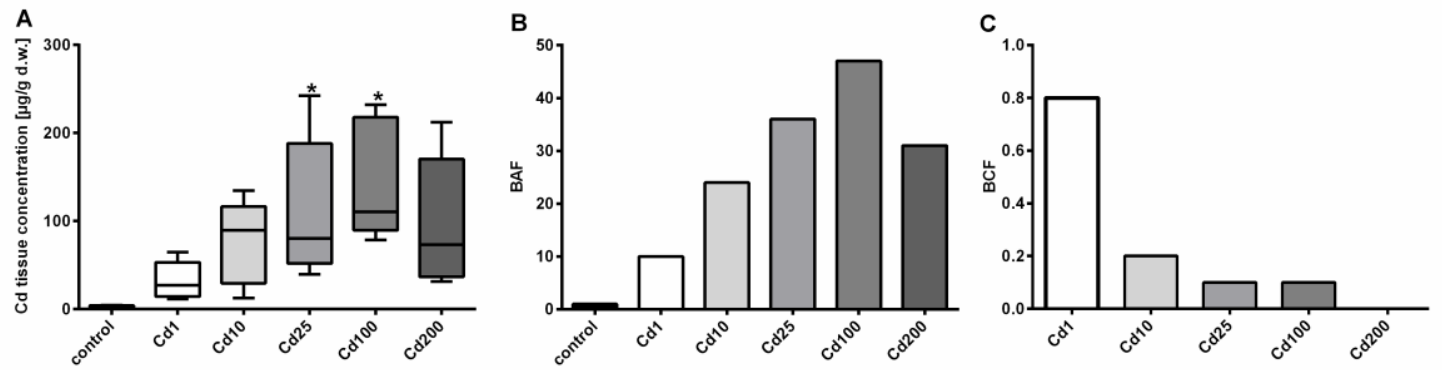

Figure 1. Dose-dependent $\mathrm{Cd}$ accumulation in A. biplicata upon $\mathrm{Cd}$ exposure through 4 days. (A) Whisker box plots showing Cd soft-tissue concentrations in $\mu \mathrm{g} / \mathrm{g}$ d.w. of controls $(n=4)$ and Cd-treated snails $(n=5$ each) from the lowest to the highest value of each treatment group. The respective box extends from the 25 th to the 75 th percentile, with the square line showing the median. Asterisks $\left(^{*}\right)$ indicate significance $(p<0.05)$ compared to control value. (B) Bar graph showing the bioaccumulation factor $(\mathrm{BAF})$ of respective treatment groups, reflecting the metal accumulation in soft tissues of treated snails, referred to controls $(\mathrm{BAF}=1)$. (C) Bar graph representing the bioconcentration factor $(\mathrm{BCF}$; for calculation see Material and Methods) for all $\mathrm{Cd}$ exposure groups. The measured $\mathrm{Cd}$ concentrations of snail cookies of each treatment group were as follows: $\mathrm{Cd} 1=38$; $\mathrm{Cd} 10=355.3 ; \mathrm{Cd} 25=804.5$; $\mathrm{Cd} 100=2692.6 ; \mathrm{Cd} 200=6396.1 \mu \mathrm{g} / \mathrm{g}$ d.w.

Cd concentrations in soft tissue of control snails ranged between 2.14 and $4.49 \mu \mathrm{g} / \mathrm{g} \mathrm{d}$.w., whereas the highest $\mathrm{Cd}$ load was assessed in snails exposed to $2693 \mu \mathrm{g} / \mathrm{g}$ d.w. $\mathrm{Cd}(\mathrm{Cd} 100)$, where the median $\mathrm{Cd}$ tissue concentration reached $145.12 \mu \mathrm{g} / \mathrm{g}$ d.w. (Figure 1). At the highest Cd exposure level of $6396 \mu \mathrm{g} / \mathrm{g}$ d.w. (Cd200), no further increase in Cd tissue accumulation was observed (Figure 1), suggesting that the accumulation curve might have reached a plateau level. Interestingly, no difference in mortality between most treatment groups ( $n=10$ each) was detected ( 1 to 2 dead snails per treatment group) except for the highest treatment group (Cd200), where three snails out of 10 died during the experiment. It is questionable, however, whether this indicates a significant increase in mortality. In addition, many snails in the highest treatment groups switched to a state of aestivation, which made it more difficult to distinguish between dead and alive individuals. Overall, it is probable that $\mathrm{Cd}$ exposure regimes applied did not reach lethal concentration levels, which suggests that $A$. biplicata must be highly tolerant against $\mathrm{Cd}$ exposure. Even though not statistically significant, an increasing trend of $\mathrm{Cd}$ accumulation of the two low $\mathrm{Cd}$-exposure groups is apparent. A possible reason for the lacking significance in these cases may be the high variability of $\mathrm{Cd}$ soft-tissue concentrations within the respective treatment groups (Figure 1A), most likely owing to differing degrees of activity and feeding rates of individual snails [14]. Whereas Cd feed concentrations of 38 and $355 \mu \mathrm{g} / \mathrm{g} \mathrm{Cd}$ d.w. in the two lowest treatment groups ( $\mathrm{Cd} 1$ and $\mathrm{Cd} 10)$ can be compared with concentrations of highly metal-polluted terrestrial habitats, this is certainly not the case for the higher $\mathrm{Cd}$ treatments $(\mathrm{Cd} 25, \mathrm{Cd} 100$, and $\mathrm{Cd} 200)$ in the present study. Cd soil concentrations of most terrestrial habitats do not exceed the range of 1 to $2 \mu \mathrm{g} / \mathrm{g}$ Cd within Europe [30], but at highly contaminated sites, Cd soil content can increase up to $232 \mu \mathrm{g} / \mathrm{g}$ d.w. [31]. Cd concentrations of litter can also vary to a great extent, and highly elevated Cd litter concentrations at contaminated sites can be detected [32,33].

Evidently, A. biplicata possesses a marked capacity for $\mathrm{Cd}$ bioaccumulation, as shown in the present study by the high $\mathrm{Cd}$ concentrations reached in the soft tissue of metal-exposed snails, in which $\mathrm{Cd}$ can be concentrated up to 47-fold referred to control individuals (Figure 1B). However, when analyzing the bioconcentration factor (BCF), A. biplicata seems not to be a "macroconcentrator" species for $\mathrm{Cd}$ (Figure 1C) in contrast to its near relative species like Helix pomatia, Arianta arbustorum, or Cornu aspersum, being able to accumulate $\mathrm{Cd}$ from the environment, with BCF values above 2 [34]. However, this observation is preliminary, considering that within the short exposure period of 4 days in the present study, steady state levels for Cd bioconcentration might not yet have been reached [34]. 
Notwithstanding the above, it appears that most terrestrial snail species (including probably A. biplicata) are suitable organisms for monitoring Cd contamination of their respective soil habitats $[5,13,35]$.

\subsection{Avoidance Behavior}

Snails of all treatment groups were photographed before and after feeding. Three different feeding categories could be distinguished (Figure 2): snails which fed regularly (F) by showing clear feeding marks on the respective snail cookies, and with parts of the cookies being scattered through multiple sites within the petri dishes. When clearly visible feeding marks on snail cookies were lacking but small parts of them were distributed within the petri dishes, snails were categorized as poor feeders (PF). Treatment groups were defined as non-feeding (NF) snails when both clear visible feeding marks and randomly distributed cookie parts within petri dishes were absent.

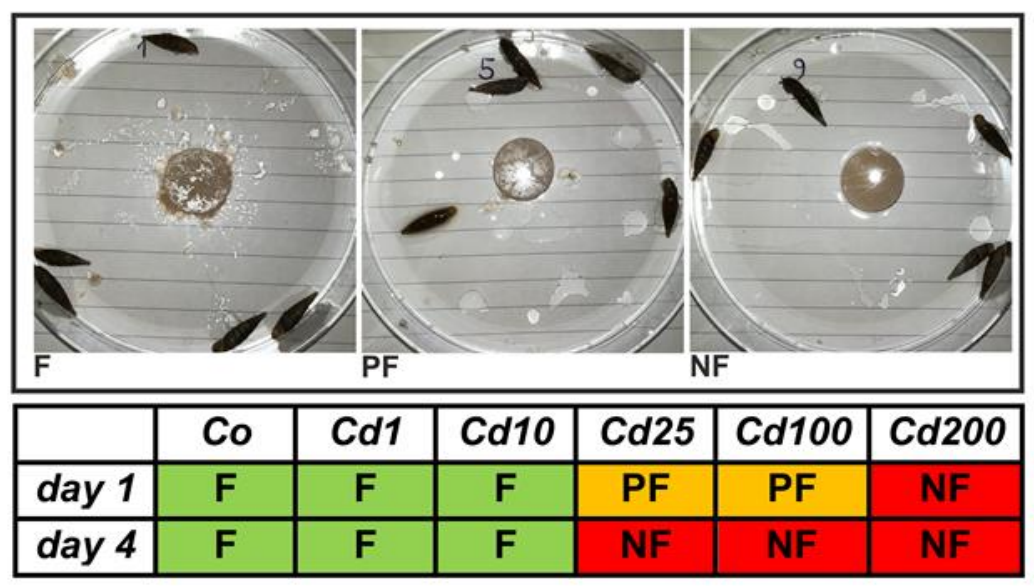

Figure 2. Feeding behavior of A. biplicata in control snails and individuals fed on Cd-contaminated cookies. The photographs illustrate the three categories of feeding $(\mathrm{F})$, poor feeding $(\mathrm{PF})$, and non-feeding (NF) in control (Co) and Cd-exposed snails (Cd1, Cd10, Cd25, Cd100, and Cd200) (for exact definition of feeding groups, see text). Cd exposure groups were defined as shown in the legend of Figure 1.

The observed feeding activity of snails decreased at higher $\mathrm{Cd}$ exposure levels (Figure 2). Controls and individuals of lower Cd treatment groups (Cd1 with 38 and Cd10 with $355 \mu \mathrm{g} / \mathrm{g} \mathrm{Cd}$ ) showed an active feeding behavior (Figure 2). Snails treated with higher Cd concentrations (Cd25 with 804.5 and Cd100 with $2692.6 \mu \mathrm{g} / \mathrm{g} \mathrm{Cd}$ ) started to feed poorly at the beginning of the experiment and stopped feeding during the end of the experiment. No feeding activity at all was observed for snails of the highest treatment group (Cd200 with $6396.1 \mu \mathrm{g} / \mathrm{g} \mathrm{Cd}$ ), even though crawling tracks were present on the surface of the respective snail cookies (Figure S1). However, individuals of this treatment group accumulated $\mathrm{Cd}$, too (Figure 1). The reason for this must evidently be $\mathrm{Cd}$ absorption through the skin of the snail's foot. In fact, dermal uptake of $\mathrm{Cd}$ and other toxic metals has frequently been reported in land snails [36-38]. Our data indicate that at lower $\mathrm{Cd}$ exposure concentrations, the detoxification system of $A$. biplicata may be sufficient for handling the apparent dietary $\mathrm{Cd}$ load. Hence, no behavioral adaptation like a reduction of feeding activity is necessary. However, when Cd exposure exceeds a certain threshold concentration, the capacity of the detoxification system is apparently overstrained and, consequently, snails adapt an avoidance behavior and/or switch into a state of inactivity, the so-called aestivation, to save themselves from severe permanent damage caused by excessive $\mathrm{Cd}$ uptake. The reduction of food consumption to avoid metal uptake has been documented for other gastropod species, too, including terrestrial snails like Cornu aspersum [39], Cepaea nemoralis [40], Theba pisana [41], and Oxyloma pfeifferi [42], or freshwater species such as Physella columbiana [43] and Lymnaea stagnalis [44]. Occasionally, this adaptive behavioral response may be inherited by snails that experienced metal pollution during their life cycle to their offspring [43]. In some cases, metal-exposed 
snails not only show a reduced feeding activity but even start to aestivate [14]. Changing to aestivation could have several benefits such as avoiding or limiting the uptake of toxic metal ions, but also restoring cellular health by fasting. It was demonstrated that in the periwinkle Littorina littorea, fasting can increase lysosomal stability, decrease lipid peroxidation (LPO), and induce autophagic cytoprotective mechanisms to remove degraded or harmful protein aggregates [45].

\subsection{Characterization of Multi-Domain MT Genes in Alinda Biplicata}

The gene structure of the two novel md-MTs ( $9 m d-M T$ and 10md-MT) of this species was disclosed for the first time in the present study and characterized over a stretch from the start to the stop codon. The most surprising feature of the $9 m d-M T$ and 10md-MT genes of A. biplicata is their lack of introns (Figure 3), resulting in a gene length of $864 \mathrm{bp}$ for the $9 m d-M T$ gene (GenBank MT084760) and $960 \mathrm{bp}$ for the 10md-MT gene (GenBank MT084761). We interpret these findings as a result of evolutionary intron loss. Intron loss can be a sign for pseudogenization [46], meaning that the respective gene is not transcribed into mRNA any more, which normally serves as a template for translation into the respective protein.

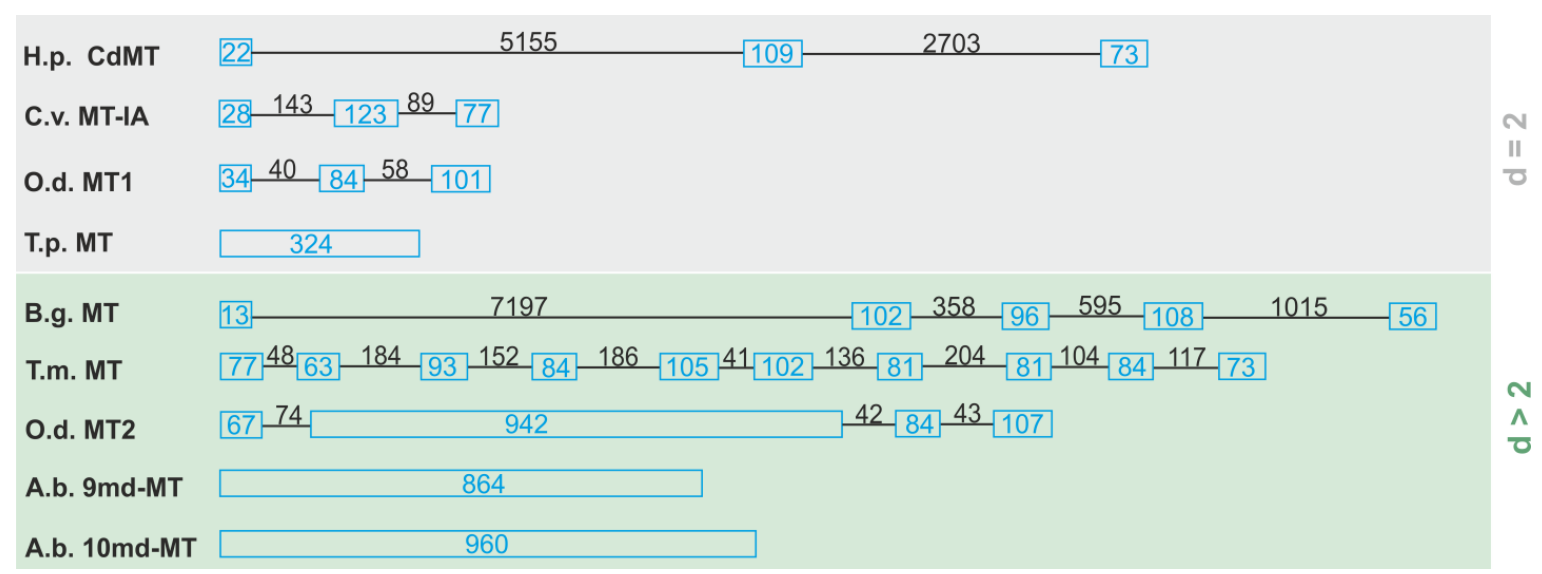

Figure 3. Outline of different gene structures of two $(d=2)$ and multi-domain $(d>2)$ MTs. Blue boxes represent the exons, introns are symbolized by lines. The exact length of exons and introns is given in $\mathrm{bp}$ (blue for exons, black for introns). Species abbreviations and references (in brackets) are as follows: O.d., Oikopleura dioica [47]; H.p., Helix pomatia [13]; B.g., Biomphalaria glabrata [48]; A.b., Alinda biplicata (this study); T.m., Tremella mesenterica [49]; C.v., Crassostrea virginica [50]; T.p., Tetrahymena pyriformis [51].

Further sequence features of pseudogenization can be mutations at the exon/intron splice sites, the presence of non-synonymous mutations like the replacement of cysteine residues, an abundance of aromatic amino acids, or the appearance of premature stop codons, as described by Moleirinho et al. (2011) to identify human MT pseudogenes [46]. However, both md-MTs of A. biplicata possess characteristic cysteine positions and lack premature stop codons. Apart from that gastropod, MTs may be an exception to the rule that the introduction of aromatic amino acids will lead to MT pseudogenes. In fact, MTs of several gastropod species like Cornu aspersum, Littorina littorea, or Pomatias elegans contain aromatic amino acids in their peptide sequences but the respective MT proteins are still functional in vivo [6,26]. All these features argue against the pseudogenization of the two intronless MT genes. Overall, the internal architecture of $M T$ genes can be very variable (Figure 3), and three different kinds of $M T$ gene structures can be distinguished: (i) a typical exon/intron structure as known for many other genes, too [13,47-50]; (ii) a deviated exon/intron structure with a large exon consisting of repeat sequences that sometimes represent multiple domains [47]; and (iii) real intronless genes where introns are not present anymore [51] (this study). In addition, the length of the introns can vary to a great extent, mostly in contrast to the rather uniform size of exons (Figure 3). So far, the only further example of an intronless MT gene structure was reported for the ciliate Tetrahymena pyriformis [51,52] (Figure 3). 
Apart from the MTs mentioned above, there are other examples of intronless genes that can be activated to yield functional mRNA transcripts, too [53,54]. In humans, most of these genes encode proteins that are involved in signal transduction, growth, proliferation, or development [55,56]. It was shown that intronless genes evolve more rapidly than spliced genes [57]. This may be a possible advantage to adapt faster to changing habitat conditions, and may confer to the two intronless $m d-M T$ genes of A. biplicata a high evolutionary potential for adaption to fluctuating environmental metal levels on an evolutionary time scale. In the case of Drosophila melanogaster, for example, DNA-mediated duplication of entire MT genes correlate with the Cd resistance of this species at a population-specific level $[29,58]$.

Furthermore, both $m d-M T$ genes of $A$. biplicata are transcribed to RNA (Figure 4) [19]. Hence, due to the lack of introns, the DNA sequence of both $m d-M T s$ matches its respective RNA transcripts (Figure 4). The shorter $9 m d-M T$ gene has a length of 864 nucleotides encoding for nine metal-binding domains, consisting of 8 repetitions (N2-8) of a primordial N-terminal domain (N1), in addition to a distinctly different C-terminal domain (C1). The second 10md-MT gene spans a length of 960 nucleotides that translate into an MT with 10 metal-binding domains, 9 of which (N2-9) represent repetitions of the $\mathrm{N}$-terminal domain (N1), in addition to a different C-terminal domain (C1) (Figure 4). The final arrangement of the respective $\mathrm{N}$ and $\mathrm{C}$-domains was achieved by comparing the resulting putative md-MT peptide sequences with already known gastropod MT structures $[25,26]$ (for detailed discussion, see Section 2.6).

To compare the single domains with each other, a BlastN (high similarity, default parameters, NCBI homepage) was performed (see Table S2). While the respective C-terminal domains of the two md-MTs are, with a sequence similarity of $98.92 \%$, highly similar among each other, no similarity can be observed between them and the repetitive N-terminal domains. On the other hand, the identity or high homology among all N-terminal domains are evident, irrespective of whether they belong to the $9 m d-M T$ or $10 m d-M T$ isoform. Yet, a comparison between $9 m d-M T$ and 10md-MT reveals that some of the N-terminal repetition domains are identical even across the two isoforms (Figure 4, Table S2). 


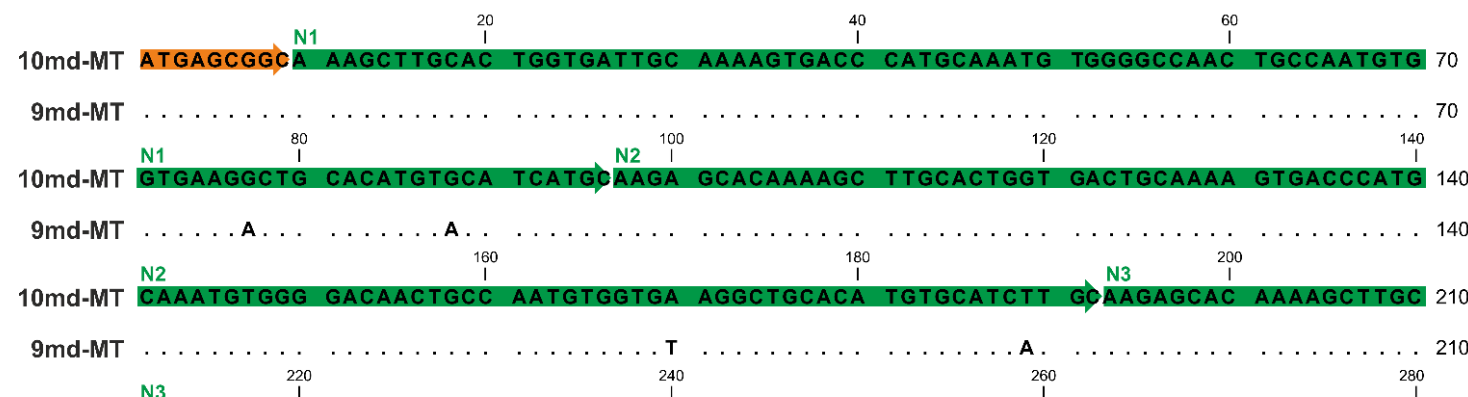

10md-MT ACTGGTGACT GCAAAAGTGA TCCATGCAAA TGTGGGGACA ACTGCCAATG TGGTGTAGGC TGCACATGTG 280

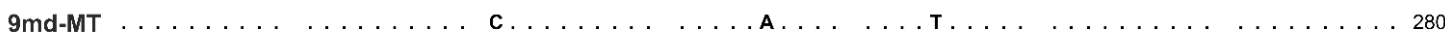
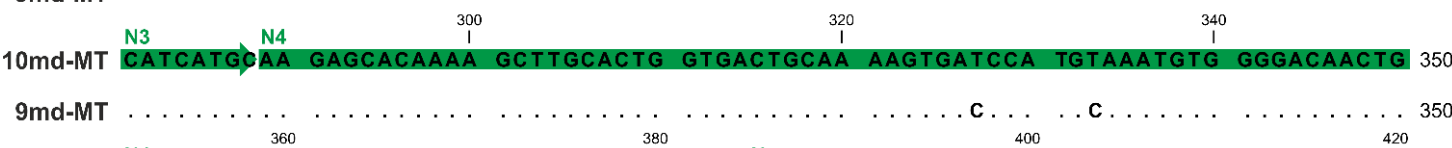

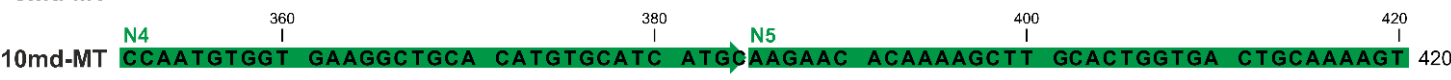

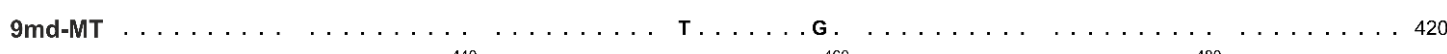

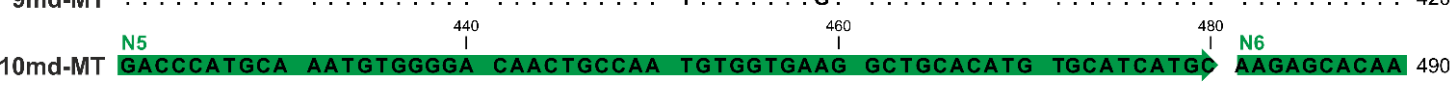
9md-Mт $\ldots \ldots \ldots \ldots \ldots \ldots \ldots \ldots$ \begin{tabular}{ccccc} 
N6 & 500 & 520 & 540 & 560 \\
\hline
\end{tabular}

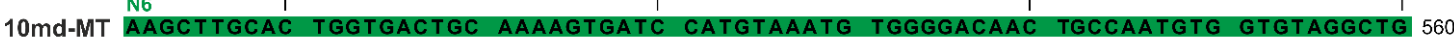

9md-MT . . . . . . . . . . . . . . . . . . . . . . . . . . . . . . . . . . . . . . . . . 480 N6 $\quad$ N7 $\begin{array}{ccc}580 & 600 & 1 \\ 1 & 1 & 1\end{array}$ 10md-MT CACATGTGCA TCATGCAAGA ACACAAAAGC TTGCACTGGT GACTGCAAAA GTGACCCATG CAAATGTGGG 630

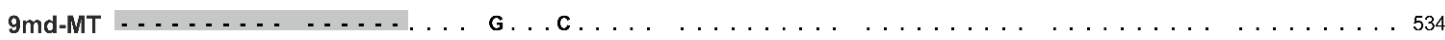
10md-MT $\stackrel{\text { N7 }}{\text { GCCAACTGTC }} \begin{gathered}640 \\ \text { AATGTGGTGA AGGCTGCACA }\end{gathered}$

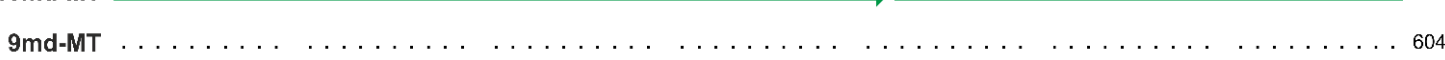

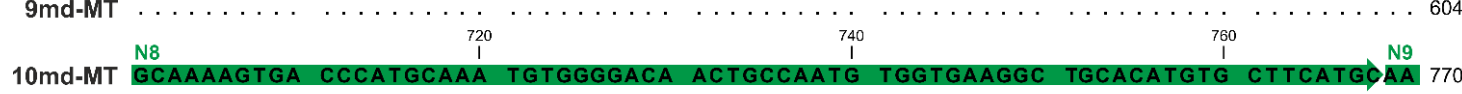

9md-Mт $\ldots \ldots \ldots \ldots \ldots \ldots \ldots \ldots \ldots$ $\begin{array}{lcccc} & 780 & 800 & 820 & 840\end{array}$

10md-MT AAACACAAAA GCTTGCACTG GTGACTGCAA AAGTGATCCA TGCAAATGTG GGGACAACTG CCAATGTGGT 840 9md-мт $\ldots \ldots \ldots \ldots \ldots \ldots \ldots \ldots \ldots \ldots$

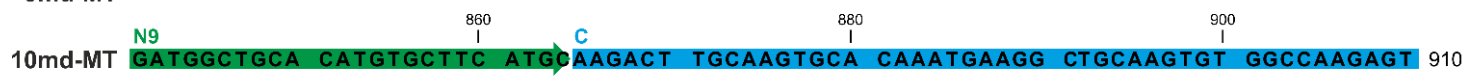
9md-мт $\ldots \ldots \ldots \ldots \ldots \ldots \ldots \ldots \ldots$

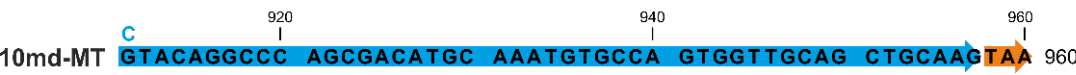
9 md-Mт $\ldots \ldots \ldots \ldots \ldots \ldots \ldots \ldots$

Figure 4. Gene/RNA sequence alignment of the two $m d-M T$ isoform genes (10md-MT and 9md-MT) of A. biplicata. The gene sequences correspond to the detected RNA sequences because introns are lacking in the two $9 m d$ and 10md-MT genes. The orange boxes indicate the respective start sequences and the stop codon. The N-terminal repetition domains (N1-N9) are highlighted through green arrows, whereas the C-terminal domain is marked in blue. Dots represent identical nucleotides present in both $m d-M T$ genes; base replacements between the two genes are indicated by respective letters. The missing sequence of the N6 domain within the $9 m d-M T$ gene is shadowed in grey.

For example, the domains N4 of $9 m d-M T$ and N2 of $10 m d-M T$ share a sequence similarity of $100 \%$. A ranking of N-terminal repeat domains according to their sequence similarity from highest to lowest homology in the two md-MT isoforms shows the following patterns:

9md-MT: N2, N4, N5, N8 $>$ N3, N9 $>$ N7 $>$ N1.

10md-MT: N3, N4, N6 > N5, N8, N2 > N9 > N7 > N1; 
In both isoforms, the domains N1 and N7 are the most divergent sequences compared to all other $\mathrm{N}$-domains within the respective $m d-M T$ gene. In the case of $\mathrm{N} 1$, the aberrance can be explained by the shorter length of this domain due to a missing linker region in the front (Figure 4). Overall, the structural organization of the md-MTs of $A$. biplicata is closely related to that of the three-domain MTs of Littorina littorea and Pomatias elegans [26,27], which can both be regarded as md-MTs with only one repetition of the $\mathrm{N}$-terminal metal-binding domain. Apart from that, it has also been demonstrated that the C-terminal metal binding domains are highly conserved among all snail MTs. At least in the three-domain MT of Littorina littorea, the C-terminal domain has assumed an important role in cooperative uploading of $\mathrm{Cd}^{2+}$ to the whole MT protein [19].

A possibility for the emergence of these $m d-M T$ intronless genes in A. biplicata could be RNA-based gene duplication by retroposition. Typical features of such retrocopies (retrogenes and retropseudogenes) are, besides the lack of introns, a spatial distribution within the genome distant from the parent genes, target site duplications, and a poly-A tail [59]. Among MTs, one example of a retropseudogene that is not transcribed into RNA is the human $\mathrm{MTII}_{\mathrm{B}}$ [60]. In contrast, some transgenes are only transcribed into RNA and can play a regulatory role [61], whereas other transgenes are transcribed to mRNAs that encode for full-length proteins [62]. Alternatively, the two $m d-M T$ genes of A. biplicata may have originated by duplication of a primordial MT gene, followed by independent duplication of the N-terminal domains in the two genes. The original introns of the two md-MT genes may thereafter have been lost over time. Several studies have shown, in fact, that intron loss is much more likely to occur than intron gain [63,64]. Another scenario would be the emergence of one $m d-M T$ gene by the process described above and a subsequent duplication of the whole $m d-M T$ gene, thereby losing or gaining additional N-terminal domains. Further studies will have to clarify by which kind of duplication events the $m d-M T$ genes of $A$. biplicata may have originated, and if the respective mRNAs are translated into full-length md-MT proteins.

\subsection{Impact of $C d$ Exposure on MT Gene Transcription in Alinda biplicata}

In order to explore whether and to which degree $\mathrm{Cd}$ accumulation in A. biplicata might be linked to MT expression, reverse transcription of $m d-M T$ genes was optimized and qRT PCR was performed. Sequence confirmation of $m d-M T$ mRNA transcripts appeared to be challenging. Upon blasting of the cDNA sequences of the CuMT of A. biplicata (GenBank: MK639793) or other known CdMTs against transcriptomic data (SRX 7671047), it appeared that the respective contigs consisted only of partial sequences of the full-length $m d-M T$ transcript (see Figure S2). A possible reason for this could be the repetitive nature of the $m d-M T$ RNA sequences [65] or the error proneness of the reverse transcription process of RNA into cDNA $[66,67]$. In a comparative approach, three different transcriptase systems, namely, the RevertAid H Minus (RA), SuperScript ${ }^{\mathrm{TM}}$ IV (SSIV) and AccuScript High Fidelity (AS), were tested (see Material and Methods). Upon PCR using CDNA-templates from all three tested reverse transcriptases, there appeared some additional bands on the gels that were not shared by all three approaches. A reason for this could be an intramolecular template switching of the respective reverse transcriptases during cDNA synthesis. In this case, the RT enzyme switches within the template from one repeat to another, which could be enhanced by secondary structures of the respective RNA template $[66,68]$. Only the approach with the AccuScript High Fidelity kit produced one single amplification band. Hence, we decided to use for our study the AccuScript High Fidelity kit (Agilent Technologies Inc., Santa Clara, CA, USA) to generate cDNAs for further downstream analysis by qRT-PCR.

MT gene expression of the md-MTs and the two-domain CuMT of controls and Cd-treated snails were quantified via qRT-PCR. It is important to stress that in the case of the two $m d-M T$ genes, the quantitative RNA measurements did not distinguish between the $9 m d-M T$ and 10md-MT isoforms (see Material and Methods for further explanation). In contrast to the increasing $\mathrm{Cd}$ concentrations in the snail tissues in a dose-dependent manner up to a threshold level (Figure 1), the influence of $\mathrm{Cd}$ exposure on $M T$ gene transcription of A. biplicata was more variable (Figure 5). 

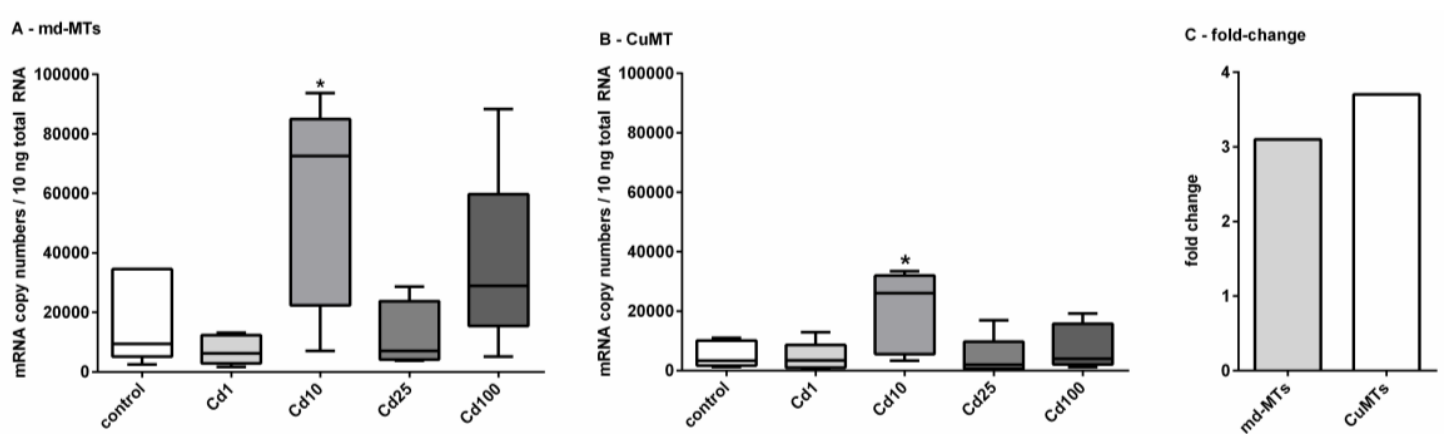

Figure 5. Impact of Cd exposure on MT gene transcription in A. biplicata. Whisker box plots for mRNA copy numbers are given for (A), showing the joined transcriptional upregulation of the two md-MT genes $(9 m d-M T+10 m d-M T)$ and $(\mathbf{B})$, of the CuMT gene in controls and Cd-treated snails $(n=5$ each) from the lowest to the highest value of each treatment group. The respective box extends from the 25th to the 75th percentile, with the square line showing the median. (C), Bar graph reflecting the fold-change of joined $m d-M T$ and CuMT transcription in snails treated with $355.3 \mu \mathrm{g} / \mathrm{g} \mathrm{Cd}(\mathrm{Cd} 10)$, referred to control levels. Cd exposure concentrations were as follows: $\mathrm{Cd} 1=38 ; \mathrm{Cd} 10=355.3 ; \mathrm{Cd} 25=$ 804.5; Cd100 = $2692.6 \mu \mathrm{g} / \mathrm{g}$ d.w. (see Section 3.2). Asterisks $\left(^{*}\right)$ indicate significance $(p<0.05)$ of mRNA copy numbers referred to respective control values.

A significant upregulation for the $m d-M T$ genes and the $C u M T$ gene was only detected in snails fed on cookies with a Cd concentration of $355.3 \mu \mathrm{g} / \mathrm{g}$ d.w. (Cd10). In this case, a 3-fold induction for the $m d-M T$ genes and a 4-fold induction for the CuMT gene were observed (Figure 5C) There might be several reasons for this variable response of $M T$ gene transcription in Cd-exposed A. biplicata. For example, under control and low-dose $\mathrm{Cd}$ exposure (Cd1) conditions, sufficient MT protein might already be available to bind the excess amounts of $\mathrm{Cd}$ and hence, no transcriptional upregulation of the respective MT genes would be necessary. In some non-exposed helicid snails, the CdMT gene is transcribed, but the respective encoded MT protein is not expressed [22]. Inhibition of mRNA translation and its activation upon stress is a phenomenon described for many different genes [69-71]. In E. coli, for example, the enzyme Aconitase B is bound to the mRNA of superoxide dismutase (SOD) and inhibits its translation under control conditions. Under oxidative stress, however, the translational inhibition by this enzyme is reversed, and so the SOD protein can be synthesized [70].

At moderately increased Cd exposure concentrations in our study (Cd10 in Figure 5), MT genes (md-MTs and CuMT) of A. biplicata are upregulated with an approximately 3.5-fold induction (Figure 5C), very probably in response to $\mathrm{Cd}$ stress in order to handle its detoxification. Such a rather moderate activation for $M T$ gene expression due to $C d$ exposure was reported for other gastropod species, too, such as Helix pomatia or Cornu aspersum [14,19], where $\mathrm{Cd}^{2+}$ ions are readily detoxified by binding to the produced CdMT proteins [6,72]. In contrast, $\mathrm{Cd}$-dependent $M T$ gene upregulation is much stronger in vertebrates like rats [73], fish [74-76], or other invertebrate species like in the earthworm Eisenia fetida [77]. When Cd exposure levels exceed a certain threshold concentration, MT gene transcription in A. biplicata is not upregulated anymore, or it may even be inhibited (Figure 5). One reason for this may be that $\mathrm{Cd}$ uptake by A. biplicata up to such high levels may lead to an exhaustion of its MT detoxification system. As a consequence, metal toxicity to the snail may increase to an excessive level as to inhibit the protein expression machinery. A strong indication for this may be the feeding avoidance behavior and inactivity of snails observed at $\mathrm{Cd}$ concentrations above a threshold level of $355.3 \mu \mathrm{g} \mathrm{Cd} / \mathrm{g}(\mathrm{Cd} 10)$ in the food cookies (Figure 2).

\subsection{Are Alinda biplicata md-MTs Involved in Cd Detoxification?}

The 10md-MT gene of A. biplicata encodes a putative md-MT protein with 319 aas, thus being the longest MT ever so far described from a mollusk species. Only for the sea squirt Oikopleura dioica a 
longer MT variant with 399 aas was reported [47]. In addition to the $10 m d-M T$, A. biplicata possesses a second large-sized md-MT isoform with 287 aas, encoded by the $9 m d-M T$ gene (Figures 4 and 6).

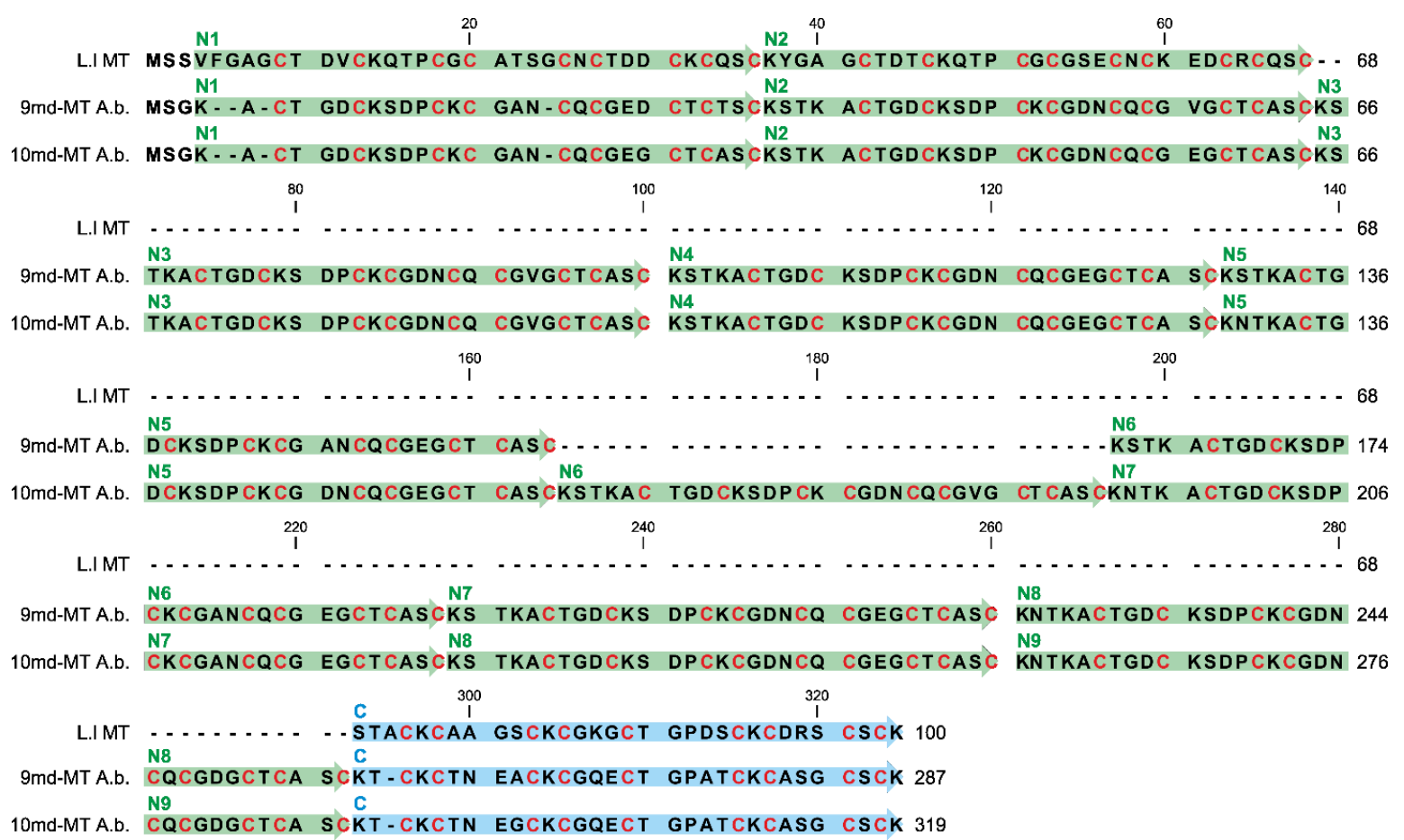

Figure 6. Alignment of putative multi-domain MT proteins from A. biplicata with the previously published 3md-MT from Littorina littorea [26,28]. N-terminal domain sequences (N1-N9) are highlighted in green, whereas the C-terminal domains are colored in blue. Cysteine residues are highlighted with red letters for $\mathrm{C}$.

A multiple alignment reveals that across all N-terminal repetition domains of 9md-MT and 10md-MT, only two variable amino acid positions are present (Figure S3A). Hence, a consensus sequence for the N-terminal domains from both md-MTs of $A$. biplicata can be assessed as follows: CTGDCKSDPCKCG $X_{1}$ NCQCG $_{2}$ GCTCASC. In this sequence, alanine (A) or aspartic acid (D) can replace each other at position $\mathrm{X}_{1}$, whereas at position $\mathrm{X}_{2}$, glutamic acid (E) can occur additionally to $A$ and D (Figure S3A). One exception of this is seen in the N1-domain of 9md-MT, which contains two additional amino acid replacements $(\mathrm{G} \rightarrow \mathrm{D}$; $\mathrm{A} \rightarrow \mathrm{T}$; Figure $\mathrm{S} 3 \mathrm{~A})$.

A comparison of amino acid sequences of these large-sized md-MTs with the three-domain MT of Littorina littorea shows the high degree of similarity between the respective N-terminal domains and their tandem repeats on the one hand, and the respective C-terminal domains on the other (Figure 6).

Since the three-domain MT of Littorina littorea clearly exhibits Cd-selective binding features [28] that were confirmed by solution NMR [26], it is suggested that, based on the high degree of sequence similarity, the two md-MTs of A. biplicata might also be Cd-specific. It also appears that both md-MTs are more closely related to other snail CdMTs, including those of Helix pomatia and Cornu aspersum (61-69\% identity), than to the respective aminoacid sequence of snail CuMT isoforms (48-54\% identity) (Figure S3B) [19]. All three MT sequences shown in Figure 6 share, in close vicinity to Cys residues, an elevated frequency of particular amino acids that were discussed to play a potential role in promoting Cd-selective binding features of the respective MT proteins (Table 1). 
Table 1. Different gastropod species MTs (left column) with abundance of amino acid residues (in single-letter codes) that are supposed to influence the metal-specific binding character of the respective MT proteins. The abundance of the selected amino acids refers to confirmed $\mathrm{Cd}$ - and Cu-specific gastropod MTs and snail md-MTs. The number (\#) of selected amino acids $(C, K, N, H)$ and the percentage (\%) of charged amino acids (caas) in relation to the whole amino acid length (last column) of the respective MT peptide sequences (including the $\mathrm{M}$ at the start position) are listed. GenBank entry numbers are as follows: H.p. CdMT: AAK84863.1; C.a. CdMT: ABL73910.1; L.1. CdMT: AST14863.1; H.p. CuMT: AAK84864.1; C.a. CuMT: ABM55268.1, A.b. md-MTs (9md-MT: MK648139; 10md-MT: MK648140).

\begin{tabular}{ccccccc}
\hline MT & \# of C & K/N Ratio & \# of H & \# caas & \% caas & Length \\
\hline Helix pomatia CdMT & 18 & $9 / 1$ & 0 & 16 & 23.90 & 67 \\
\hline Cornu aspersum CdMT & 18 & $8 / 2$ & 0 & 14 & 20.90 & 67 \\
\hline Littorina littorea CdMT & 27 & $10 / 2$ & 0 & 21 & 21 & 100 \\
\hline Alinda biplicata 9md-MT & 81 & $36 / 10$ & 0 & 66 & 23 & 287 \\
\hline Alinda biplicata 10md-MT & 90 & $40 / 13$ & 0 & 74 & 23.20 & 319 \\
\hline Alinda biplicata CuMT & 17 & $6 / 6$ & 1 & 11 & 16.90 & 65 \\
\hline Helix pomatia CuMT & 18 & $5 / 6$ & 1 & 12 & 18.50 & 65 \\
\hline Cornu aspersum CuMT & 17 & $3 / 9$ & 1 & 11 & 16.90 & 65 \\
\hline
\end{tabular}

Namely, a high preponderance of lysine $(\mathrm{K})$ over asparagine $(\mathrm{N})$ residues, as observed in the two md-MTs of A. biplicata, was considered to be a typical feature of Cd-selective snail MTs (Table 1) [24,78]. In the MT of Biomphalaria glabrata, for example, the replacement of a lysine by an asparagine residue increased the $\mathrm{Cu}$ but not the Cd-binding capability of the respective MT protein [79]. In addition, Cd-selective snail MTs typically exhibit a higher content of charged amino acids, compared to non-metal-specific variants [24] (Table 1). This may contribute to a tighter protein folding caused by increased electrostatic interactions $[24,80]$. From a biological point of view, a stiffer protein folding may help to prevent the loss of already bound $\mathrm{Cd}^{2+}$ ions, which would otherwise cause intracellular damage upon release. Further, the occurrence of histidine $(\mathrm{H})$, which is frequently observed in snail CuMTs, is missing in the two md-MTs of A. biplicata (Figure 6, Table 1). Even though this amino acid normally decreases the Cu-binding ability of MTs, it seems to play a vital role in these proteins for an optimal balance between $\mathrm{Cu}$ binding and $\mathrm{Cu}$ release, in order to fulfill its biological role in $\mathrm{Cu}$ homeostasis [81,82].

In addition to all these primary structure features, the $m d-M T$ genes of A. biplicata exhibit a transcription pattern that is similar to other Cd-specific snail MTs [14,22]. Seemingly higher basal $m d-M T$ gene transcription levels in unexposed individuals, and significantly higher gene transcription values in Cd-treated A. biplicata snails, compared to the respective CuMT gene, strongly suggest an elevated expression rate and Cd-dependent activation of the $m d-M T$ genes of this species and hence, their involvement in Cd inactivation (Figure 7). This is in accordance with the transcriptional expression patterns of the CdMT genes in the helicid snail species Helix pomatia and Cornu aspersum [22]. A minor different transcription pattern is observed for the CuMT gene of A. biplicata, which, contrary to $\mathrm{CuMT}$ genes of other snails [22,83], is slightly upregulated by $\mathrm{Cd}$ exposure, too (Figures 5 and 7). This indicates that the $\mathrm{CuMT}$ gene of $A$. biplicata may behave more like an unspecific $\mathrm{Cd} / \mathrm{CuMT}$ rather than a true CuMT [6,84]. 


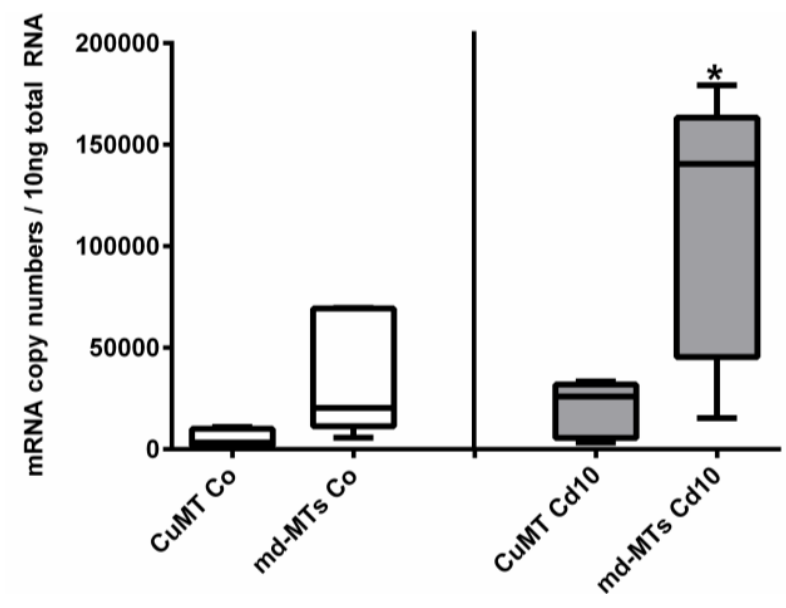

Figure 7. Comparison of mRNA expression levels of CuMT versus joined md-MT genes (9md-MT+ $10 m d-M T)$ in A. biplicata. Whisker box plots from the lowest to the highest values, showing transcription levels for controls (white whisker box plots, left-hand side) and snails exposed to $355 \mu \mathrm{g} / \mathrm{g}$ d.w. (Cd10) (grey whisker box plots, right-hand side; $n=5$ each). The box of each treatment group extends from the 25 th to the 75 th percentile, with the square line showing the median. Asterisks $\left({ }^{*}\right)$ indicate significance $(p<0.05)$ upon comparison between $C u M T$ transcription versus $m d-M T$ transcription in exposed snails $(\mathrm{Cd} 10)$.

\subsection{Structural and Evolutionary Considerations of the Emergence of md-MTs in Alinda biplicata}

An additional enhancement of the Cd-inactivating capacity of 9md-MT and 10md-MT may arise from their multi-domain structure, which strongly suggests an increased metal-binding capacity of the two md-MTs of $A$. biplicata due to their correspondingly higher $\mathrm{Cd}^{2+}$ binding stoichiometry. In other snail species, for example, the Cd-binding stoichiometry increases from 6 to $9 \mathrm{Cd}^{2+}$ ions bound per protein molecule if an additional metal-binding domain is added to the protein through evolutionary optimization. This was experimentally demonstrated by NMR or mass spectrometry for the Cd-specific MT of Littorina littorea [26,28] (Figure 8). Interestingly, in Cu-specific MTs of fungi such as Tremella mesenterica and Crypotococcus neoformans, too, the addition of Cys-containing tandem repetitions increases their $\mathrm{Cu}$-binding capacity $[49,78,85]$.

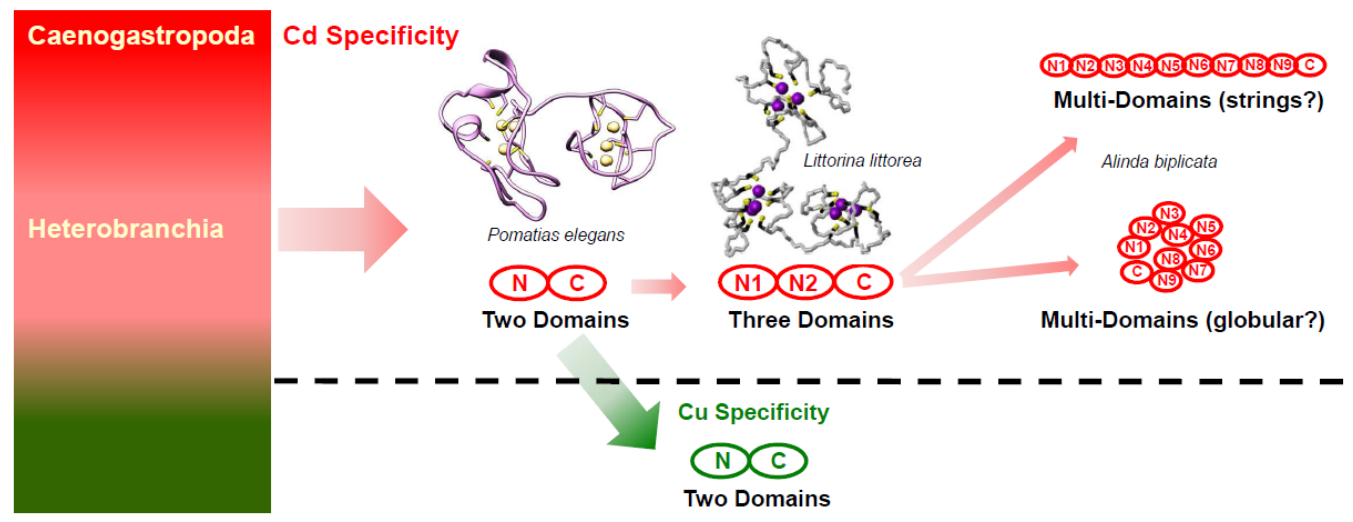

Figure 8. Hypothesis of evolution of metal-specificity and structure in MTs of the two gastropod clades Heterobranchia and Caenogastropoda (left-hand, multi-colored box). Two-domain or multi-domain Cd-specific MTs (CdMTs) in Caneogastropoda and Heterobranchia are shadowed in pink. Two-domain $\mathrm{Cu}$-specific MTs (CuMTs) in some lineages of Heterobranchia are shadowed in green. Adapted from Dallinger 2018 [86]. 
If the binding stoichiometry of $6 \mathrm{Cd}^{2+}$ ions per domain is extrapolated from so-far known two- or three-domain snail CdMTs $[23,26]$ to the md-MTs of $A$. biplicata, we would expect a binding stoichiometry of $27 \mathrm{Cd}^{2+}$ ions for the 9md-MT, and of $30 \mathrm{Cd}^{2+}$ for the 10md-MT, respectively. Consequently, this would attribute to the two md-MTs of A. biplicata, the highest Cd-binding capacity ever observed in any MT molecule. How such long md-MTs are organized in their tertiary architecture still remains unclear. One possibility would be to assume a globular structure or, as an alternative hypothesis, the domains could also be organized as strings (Figure 8). This is relevant because the three-dimensional structure has implications on the degree of reciprocal contacts of the single domains to each other, which in turn might influence their metal loading capacity, as shown in the three-domain MT of Littorina littorea [19]. Further studies will be needed to elucidate the tertiary organization and Cd binding capability of such long md-MTs in snails.

\section{Material and Methods}

\subsection{Animal Rearing and Acclimatization}

Individuals of Alinda biplicata (A.b.) were collected in summer 2017 and 2018 from mural structures in the vicinity of the department of zoology (Technikerstraße 25, A-6020 Innsbruck) of the University of Innsbruck, Austria. Snails were acclimatized in transparent octagonal plastic boxes (diameter: $12 \mathrm{~cm}$; height: $6 \mathrm{~cm}$ ) without substrate and water to keep them inactive under stable laboratory conditions ( $12 \mathrm{~h}$ dark $/ 12 \mathrm{~h}$ light and temperature $20^{\circ} \mathrm{C}$ ) for one to two weeks. Subsequently, snails were divided into six experimental groups with 10 adult snails each, and five snails per treatment group were put into petri dishes $(92 \times 16 \mathrm{~mm})$ (Sarstedt, Nümbrecht, Germany). Adult individuals were identified by the number of whorls (minimum 10) and the formation of the lip and closing apparatus [2].

\subsection{Cd Exposure and Tissue Dissection}

The control group was supplied with uncontaminated snail cookies $(1 \mu \mathrm{g} \mathrm{Cd} / \mathrm{g} \mathrm{d}$.w.), whereas $\mathrm{Cd}$-treated snails were fed on Cd-containing snail cookies through four days. Snail cookies were produced as follows: $2 \mathrm{~g}$ Agar Kobe-Kobe I (Roth, Karlsruhe, Germany), $0.66 \mathrm{~g} \mathrm{CaCO}_{3}$ (Merck Chemicals, Vienna, Austria) and $0.25 \mathrm{~g}$ algae flakes Novo Malawi (JBL GmbH Co KG, Neuhofen, Germany) were dissolved in $85 \mathrm{~mL}$ deionized water and heated up in the microwave for approx. $30 \mathrm{~s}$. After cooling down the mixture, following amounts of a $1 \% \mathrm{CdCl}_{2}$ solution (Sigma Aldrich by Merck, Darmstadt, Germany) were added: $0.01 \mathrm{~mL}(\mathrm{Cd} 1), 0.1 \mathrm{~mL}(\mathrm{Cd} 10), 0.25 \mathrm{~mL}(\mathrm{Cd} 25), 1 \mathrm{~mL}$ (Cd100), and $2 \mathrm{~mL}(\mathrm{Cd} 200)$. The subsequently measured $\mathrm{Cd}$ concentrations ( $\mu \mathrm{g} / \mathrm{g}$ dry weight) were 1 (controls), 38 (Cd1), 355.3 (Cd10), 804.5 (Cd25), 2692.6 (Cd100), and 6396.1 (Cd200), respectively. For exposure, cookies were placed in the middle of lidded plastic petri dishes (Saarstedt, Nümbrecht, Germany) along with 5 individual snails per petri dish. During exposure, small water drops were put into the petri dishes and on snail cookies every day to prevent desiccation. After four days of $\mathrm{Cd}$ exposure, individuals were sacrificed on an ice-cooled aluminum plate intermittently cleaned with RNase AWAY ${ }^{\circledR}$ (Sigma Aldrich by Merck, Darmstadt, Germany) and 70\% ethanol. Multi-tissue aliquots from five individuals of each experimental group were stored separately in RNAlater ${ }^{\circledR}$ (Fisher Scientific, Vienna, Austria) at $-80^{\circ} \mathrm{C}$ for RNA isolation. The remaining parts of soft tissues were collected for subsequent measurement of $\mathrm{Cd}$ tissue concentrations ( $n=5$ per experimental group).

For DNA isolation, additional snails were collected from the same site and sacrificed as described before. Multi-tissue parts of three adult individuals were pooled to one sample and stored in RNAlater ${ }^{\circledR}$ (Fisher Scientific, Vienna, Austria) at $-80^{\circ} \mathrm{C}$ for further processing.

\subsection{Cd Analysis}

Sample digestion and analysis of $\mathrm{Cd}$ tissue concentrations were performed as described previously [27]. Shortly, a 1:1 mixture of nitric acid (65\%) (Suprapur, Merck, Darmstadt, Germany) and deionized water were pipetted into lidded Eppendorf tubes containing the oven-dried samples 
(multi-tissue samples, snail cookies, and reference material) and digested under pressure in a heated $\left(70{ }^{\circ} \mathrm{C}\right)$ aluminum block. Cd concentrations were measured by furnace atomic absorption spectrophotometry (Z-8200 Polarized Zeeman atomic absorption spectrophotometer with SSC-300 auto sampler; Hitachi, Üdern, Germany). The system was calibrated with diluted Cd solutions from a 1000 ppm Titrisol Cd Standard (Merck, Darmstadt, Germany). TORT-2 lobster hepatopancreas (NRC, Ottawa, Canada) was used as a certified standard reference material. The mean concentration value of the measured standard reference material $(27.24 \mu \mathrm{g} / \mathrm{g}$ d.w.) was within the specified range.

The bioaccumulation factor (BAF) was calculated by dividing the mean of $\mathrm{Cd}$ tissue concentrations of the respective $\mathrm{Cd}$ exposure group by the mean of $\mathrm{Cd}$ tissue concentrations of controls. For calculation of the bioconcentration factor (BCF), the mean of $\mathrm{Cd}$ tissue concentrations of controls was first subtracted from the mean $\mathrm{Cd}$ tissue concentrations of every $\mathrm{Cd}$-exposure group. Subsequently, the respective mean value of $\mathrm{Cd}$ treatment groups was divided by the measured $\mathrm{Cd}$ concentration of the respective snail cookie.

\subsection{DNA Isolation and Long Distance (LP)-PCR of md-MT Genes}

All samples were homogenized with a Precellys ${ }^{\circledR}$ homogenizer (Bertin Instruments, Montigny-le-Bretonneux, France). Genomic DNA was obtained using the DNeasy Plant Mini Kit (Qiagen, Hilden, Germany) and quality was assessed visually by agarose gel electrophoresis. In order to obtain longer fragments upon amplification of the $m d-M T$ genes, the Platinum ${ }^{\mathrm{TM}} \mathrm{SupferFi}^{\mathrm{TM}}$ Green PCR Master Mix (Invitrogen, Thermo Fisher Scientific, Waltham, MA, USA) was applied for PCR amplification (for primers and PCR setup, see Table S2). PCR products were separated on a 1.5\% agarose gel (Biozym, Hessisch Oldendorf, Germany) by electrophoresis. Gene-specific bands were excised, purified with the QIAquick ${ }^{\mathrm{TM}} \mathrm{Gel}$ Extraction Kit (Qiagen, Hilden, Germany) and cloned with the TOPO ${ }^{\text {TM }}$ XL-2 Complete PCR Cloning Kit (Invitrogen, Thermo Fisher Scientific, Waltham, MA, USA) for Sequencing (Invitrogen, Thermo Fisher Scientific, Waltham, MA, USA). Insert-containing plasmids were purified using the QIAprep Spin Miniprep Kit (Qiagen, Hilden, Germany) and sent to Microysnth AG (Balgach, Switzerland) for Sanger sequencing.

\subsection{RNA Isolation, Quantification and cDNA Synthesis}

All samples were homogenized with a Precellys ${ }^{\circledR}$ homogenizer (Bertin Instruments, Montigny-le-Bretonneux, France). Total RNA was isolated by applying the RNeasy Plant Mini Kit (Qiagen, Hilden, Germany), including a DNase I digestion step according to the manufacturer's instruction. RNA integrity was checked by agarose gel electrophoresis. RNA concentrations were estimated applying the Quant-iT ${ }^{\mathrm{TM}}$ RiboGreen ${ }^{\circledR}$ RNA Assay Kit (Life Technologies Corporation, Carlsbad, CA, USA) with the Victor ${ }^{\mathrm{TM}}$ X4 2030 Multilabel Reader (Perkin Elmer, Waltham, MA, USA). To minimize the probability of generating artificial sequences, we decided to test three different transcriptase systems to optimize cDNA synthesis for further downstream analyses. For confirmation of $m d-M T$ mRNA sequences [19], cDNAs were generated applying three different reverse transcriptase systems, namely, RevertAid H Minus Reverse Transcriptase (Thermo Fisher Scientific, Waltham, MA, USA), SuperScript ${ }^{\mathrm{TM}}$ IV Reverse Transcriptase (Thermo Fisher Scientific, Waltham, MA, USA), and AccuScript High Fidelity Reverse Transcriptase (Agilent Technologies Inc., Santa Clara, CA, USA) according to the instructions of the manufacturers. All three reverse transcriptases are RNase H-deficient enzymes derived from the Moloney murine leukemia virus (MMLV). After generating cDNAs, as stated in the respective protocol of each enzyme, LD PCR was performed with gene-specific primers (see Table S2) applying the Advantage ${ }^{\circledR} 2$ PCR Kit (Clontech, Takara Bio Europe, Saint-Germain-en-Laye, France). When analyzing PCR products using CDNAs generated with RA and SSIV as a template, multiple bands were abundant. In contrast, amplification products derived from LD PCR with cDNA-templates generated by AS clearly showed less visible bands (Figure 9). However, PCR products of all cDNAs possessed the most prominent band with a length of approximately $1000 \mathrm{bp}$ (Figure 9). 


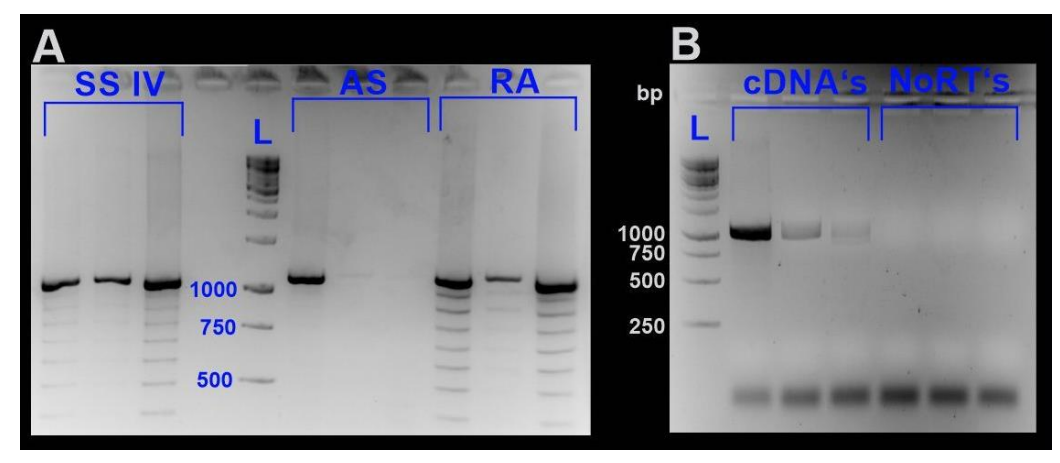

Figure 9. Gene-specific LD-PCR of the $m d-M T s$ using cDNA templates generated by three different reverse transcriptase systems. (A) PCR products using CDNAs as a template, which were generated by three different reverse transcriptases, namely, SuperScript ${ }^{\mathrm{TM}}$ IV (SSIV), AccuScript High Fidelity (AS), and RevertAid H Minus (RA). (B) Shows PCR products using cDNAs generated by reverse transcription with AccuScript High Fidelity. In addition, the respective NoRT's (see Section 3.6) are shown as a negative control to exclude contamination of the cDNAs with genomic DNA. Abbreviations: L., ladder.

As shown by Cocquet et al. [66], reverse transcriptases with an enhanced thermostability can lead to overcoming the generation of artificial bands. However, this was not true in our case. The optimal working temperature of AS and RA it at $42{ }^{\circ} \mathrm{C}$. SSIV has an even higher temperature optimum, and cDNA generation was performed at an incubation temperature at $55^{\circ} \mathrm{C}$, as recommended by the protocol. For sequence confirmation, the most prominent gene-specific bands shared by PCR products of all three reverse transcriptases were excised, purified with the QIAquick ${ }^{\mathrm{TM}}$ Gel Extraction Kit (Qiagen, Hilden, Germany) and sent to Microsynth for Sanger sequencing (Microsynth AG, Balgach, Switzerland). Due to sometimes low sequence quality of the contained sequences, cloning of clean PCR products was performed with the pCR $^{\mathrm{TM}} 4$-TOPO ${ }^{\circledR}$ vector of the TOPO ${ }^{\circledR}$ TA Cloning ${ }^{\circledR}$ Kit for Sequencing (Invitrogen, Thermo Fisher Scientific, Waltham, MA, USA). Insert-containing plasmids were purified using the QIAprep Spin Miniprep Kit (Qiagen, Hilden, Germany) and sent to Microysnth AG (Balgach, Switzerland) for Sanger sequencing. Consequently, we used AccuScript to generate cDNAs for further downstream analysis like qRT-PCR.

\subsection{Quantification of MT Gene Transcription by Quantitative RealTime PCR ( $q R T-P C R)$}

For qRT PCR, $450 \mathrm{ng}$ total RNA was used in a 20- $\mu \mathrm{L}$ approach for cDNA synthesis applying the AccuScript High Fidelity Reverse Transcriptase (Agilent Technologies Inc., Santa Clara, CA, USA). To exclude genomic contamination, NoRTs were generated treated in the same way as all other samples objected to cDNA synthesis, but without the addition of the reverse transcriptase. Gene-specific primers were designed with Primer Express 3.0 software (Applied Biosystems, Foster City, CA, USA) (see Table 2). 
Table 2. Characterization of gene-specific primers used for MT mRNA quantification. Besides the sequence and length of the respective primer, also the primer efficiencies of both primer pairs estimated by generation of a standard curve are reported. Even though the primer efficiency of the second primer pair ( $m d-M T s)$ is below $90 \%$, this combination was used due to length limitation of the respective $m d-M T$ mRNA sequences.

\begin{tabular}{|c|c|c|c|c|}
\hline Primer & Sequence $5^{\prime} 3^{\prime}$ & Length [bp] & Conc. [nm] & Primer Efficiency \\
\hline CuMT S & $\begin{array}{c}\text { GCC TGC AAC } \\
\text { AGC AAT CCA T }\end{array}$ & 19 & 900 & \multirow[t]{2}{*}{$94 \%$} \\
\hline CuMT AS & $\begin{array}{l}\text { AAC AGG CAG } \\
\text { CCC CAC ATT T }\end{array}$ & 19 & 900 & \\
\hline md-MT S & $\begin{array}{c}\text { GTG GTG ATG } \\
\text { GCT GCA CAT GT }\end{array}$ & 20 & 900 & \multirow[t]{2}{*}{$88 \%$} \\
\hline md-MT AS & $\begin{array}{c}\text { CGC TGG GCC } \\
\text { TGT ACA CTC TT }\end{array}$ & 20 & 900 & \\
\hline
\end{tabular}

To avoid multiple binding to the highly conserved repetitive sequences of the N-domains within the respective $m d-M T$ gene and between both $m d$-MTs (see Figure 4, Table S1), the C-domain was used for primer design. Consequently, the primer pair can bind only one time to one RNA transcript because the $\mathrm{C}$-domain is present only once within the respective $m d-M T$ isoform (Figure 4). However, due to high sequence similarity of the C-domains between the $9 m d-M T$ and $10 d m-M T$ sequences (see Figure 4), it was not possible to evaluate the RNA expression level of the two single $m d-M T$ isoforms independently. For optimization, a primer matrix was applied. The PCR products of the optimal primer concentrations (see Table 2 ) were obtained, cleaned, and cloned into a pCR ${ }^{\mathrm{TM}} 4-\mathrm{TOPO}{ }^{\circledR}$ vector, and resulting plasmids were sequenced (see detailed description above). Subsequently, calibration curves for both amplicons (Amplicon length: CuMT = 58 bp; md-MT = 89 bp) were established (CuMT: $y=-3.4765 x+34.426 ;$ md-MT: $y=-3.6511 x+38.629)$. To compare the expression levels of the two different amplicons, the PCR efficiency of the md-MTs was adjusted to 94\%, as described in Pérez et al. (2013) [87]. Transcripts were quantified in a 10- $\mu$ l approach using the Power SYBR ${ }^{\circledR}$ Green PCR Master Mix (Applied Biosystems by Thermo Fisher Scientific, Waltham, MA, USA) with the QuantStudio ${ }^{\text {TM }} 3$ (Applied Biosystems by Thermo Fisher Scientific, Waltham, MA, USA). The PCR amplification protocol was as followed: one initial denaturation step for $10 \mathrm{~min}$ at $95^{\circ} \mathrm{C}$ followed by 40 cycles denaturation for $15 \mathrm{~s}$ at $95^{\circ} \mathrm{C}$ and annealing/extension for $1 \mathrm{~min}$ at $60{ }^{\circ} \mathrm{C}$.

\subsection{Statistics}

Data were analyzed and graphs were prepared using GraphPad Prism (Version 6.01) (GraphPad Software, San Diego, CA, USA). Significant outliers, proofed by the Grubb's outlier test, were removed. Data were tested for normality using the Shapiro-Wilk normality test. All data were normally distributed. To analyze the different treatment groups, a Holm-Sidak multiple comparison test was applied. Significance level was set at $p<0.05$. Sequences were analyzed and aligned in CLC Main Workbench 6.9 (Quiagen, Aarhus, Denmark), and the respective figures were refined in CorelDRAW X6 (Corel Corporation, Ottawa, ON, Canada). Gel images were taken with a Herolab Camera system using the E.A.S.Y Win32 program for visualization (Herolab, Wiesloch, Germany).

\section{Conclusions}

Cd accumulation and potential detoxification mechanisms were explored in the little terrestrial door snail, A. biplicata. Our data show that $A$. biplicata possesses great potential for $\mathrm{Cd}$ accumulation paired with a behavioral feeding avoidance strategy when exposed to excessively high $\mathrm{Cd}$ concentrations in the feed. The role of Cd-specific multidomain-MTs (9md-MT and 10md-MT) as potential candidates for $\mathrm{Cd}$ detoxification is discussed. In summary, our results contribute novel data to our knowledge on the metal handling strategy of $A$. biplicata and report for the first time the gene structure, mRNA expression, and amino acid protein sequence of such long md-MTs (domain $>3$ ) in the gastropod species. 
Supplementary Materials: The following are available online at http://www.mdpi.com/1422-0067/21/5/1631/s1, Figure S1: Documented feeding behavior of controls and snails exposed to increased concentrations of Cd, Figure S2: Alignments of partial md-MT peptide sequences with the full-length 10md-MT. Figure S3: (A) Alignmnent of all N-domains of the 9md-MT and 10md-MT of Alinda biplicata; (B) Sequence coverage of the 9md-MT and 10md-MT consensus sequences of Alinda biplicata $(\mathrm{Ab})$ with $\mathrm{Cd}$ - and $\mathrm{Cu}$-specific MTs of helicid snails Table S1: Sequence comparison off all single domains of the 9md-MT (9N1-9N9; 9C) and 10md-MT (10N1 - 10N9, 10C) of Alinda biplicata; Table S2: Characterization of gene specific primers and PCR parameters used for amplification of the $9 m d$ and $10 m d-M T$ mRNA.

Author Contributions: R.D. supervised and coordinated the research. R.D. and V.P.-M. designed the exposure experiments. S.K. conducted the Cd exposure experiments. S.K. and M.D. measured Cd concentrations of tissues and snail cookies. V.P.-M. and S.K. performed sequence characterization of $m d-M T$ genes and optimization of cDNA synthesis. V.P.-M. performed qRT PCR measurements. V.P.-M. analyzed the data and discussed the results together with R.D. R.D. and V.P.-M. prepared the manuscript. All co-authors approved the manuscript before submission. All authors have read and agreed to the published version of the manuscript.

Funding: This work was supported by two cooperation grants from the Austrian Science Fund to R.D. (DACH grant No I 11482-N28; DACH grant No I 13032-B21). V.P.-M. was funded by a grant for young scientists at the University of Innsbruck.

Acknowledgments: The authors especially thank Michael Niederwanger and Tania Holtzem for support and troubleshooting.

Conflicts of Interest: The authors declare no conflict of interest.

\section{References}

1. Kerney, J.M.P.; Cameron, R.A.D.; Jungbluth, J.H. Die Landschnecken Nord-und Mitteleuropas; Verlag Paul Parey: Hamburg/Berlin, Gernamy, 1983; p. 384.

2. Maltz, T.K.; Sulikowska-Drozd, A. Life History of Alinda biplicata (Montagu, 1803) (Gastropoda: Pulmonata: Clausiliidae) Based on Five-Year Laboratory Observations. Ann. Zool. 2012, 62, 789-807. [CrossRef]

3. Storey, K.B.; Storey, J.M. Metabolic rate depression in animals: Transcriptional and translational controls. Biol. Rev. Camb. Philos. Soc. 2004, 79, 207-233. [CrossRef] [PubMed]

4. Storey, K.B.; Storey, J.M. Aestivation: Signaling and hypometabolism. J. Exp. Biol. 2012, 215, 1425-1433. [CrossRef] [PubMed]

5. Dallinger, R.; Lagg, B.; Egg, M.; Schipflinger, R.; Chabicovsky, M.-K. Cd Accumulation and Cd-Metallothionein as a Biomarker in Cepaea hortensis (Helicidae, Pulmonata) from Laboratory Exposure and Metal-polluted Habitats. Ecotoxicology 2004, 13, 757-772. [CrossRef] [PubMed]

6. Hispard, F.; Schuler, D.; de Vaufleury, A.; Scheifler, R.; Badot, P.M.; Dallinger, R. Metal Distribution and Metallothionein Induction After Cadmium Exposure in the Terrestrial Snail Helix Aspersa. Environ. Toxicol. 2008, 27, 1533-1542. [CrossRef] [PubMed]

7. Chabicovsky, M.; Klepal, W.; Dallinger, R. Mechanisms of cadmium toxicity in terrestrial pulmonates: Programmed cell death and metallothionein overload. Environ. Toxicol. Chem. 2004, 23, 648-655. [CrossRef]

8. Dallinger, R.; Berger, B.; Gruber, C.; Hunziker, P.; Stürzenbaum, S. Metallothioneins in terrestrial invertebrates: Structural aspects, biological significance and implications for their use as biomarkers. Cell. Mol. Biol. 2000, 46, 331-346.

9. Capdevila, M.; Bofil, R.; Palacios, Ò.; Atrian, S. State-of-the-art of Metallothioneins at the beginning of the 21st century. Coord. Chem. Rev. 2012, 256, 46-62. [CrossRef]

10. Egli, D.; Yepiskoposyan, H.; Selvaraj, A.; Balamurugan, K.; Rajaram, R.; Simons, A.; Multhaup, G.; Mettler, S.; Vardanyan, A.; Georgiev, O.; et al. A family knockout of all four Drosophila metallothioneins reveals a central role in copper homeostasis and detoxification. Mol. Cell. Biol. 2006, 26, 2286. [CrossRef]

11. Kimura, T.; Kambe, T. The functions of metallothionein and ZIP and ZnT transporters: An overview and perspective. Int. J. Mol. Sci. 2016, 17, 336. [CrossRef]

12. Baird, S.K.; Kurz, T.; Brunk, U.T. Metallothionein protects against oxidative stress-induced lysosomal destabilization. Biochem. J. 2006, 394, 275-283. [CrossRef] [PubMed]

13. Egg, M.; Höckner, M.; Brandstätter, A.; Schuler, D.; Dallinger, R. Structural and bioinformatic analysis of the Roman snail Cd-Metallothionein gene uncovers molecular adaptation towards plasticity in coping with multifarious environmental stress. Mol. Ecol. 2009, 18, 2426-2443. [CrossRef] [PubMed] 
14. Pedrini-Martha, V.; Niederwanger, M.; Kopp, R.; Schnegg, R.; Dallinger, R. Physiological, Diurnal and Stress-Related Variability of Cadmium-Metallothionein Gene Expression in Land Snails. PLoS ONE 2016, 11, e0150442. [CrossRef]

15. Tamait, K.T.; Liu, X.; Silar, P.; Sosinowski, T.; Thiele, D.J. Heat Shock Transcription Factor Activates Yeast Metallothionein Gene Expression in Response to Heat and Glucose Starvation via Distinct Signalling Pathways. Mol. Cell. Biol. 1994, 14, 8155-8165. [CrossRef] [PubMed]

16. Moschovaki-Filippidou, F.; Itziou, A.; Dimitriadis, V.K. Effect of starvation and hibernation on the values of five biomarkers of general and specific stress using the land snail Eobania Vermiculata. Comp. Biochem. Physiol. B Biochem. Mol. Biol. 2013, 165, 236-242. [CrossRef]

17. Kojima, Y.; Binz, P.A.; Kägi, J.H.R. Nomenclature of metallothionein: Proposal for a revision. In Metallothionein IV; Klaassen, C.D., Ed.; Birkhäuser Basel: Basel, Switzerland, 1999; pp. 3-6. ISBN 978-3-0348-8847-9.

18. Pérez-Rafael, S.; Mezger, A.; Lieb, B.; Dallinger, R.; Capdevila, M.; Palacios, Ò.; Atrian, S. The metal binding abilities of Megathura crenulata metallothionein (McMT) in the frame of Gastropoda MTs. J. Inorg. Biochem. 2012, 108, 84-90. [CrossRef]

19. Dallinger, R.; Zerbe, O.; Baumann, C.; Egger, B.; Capdevila, M.; Palacios, O.; Albalat, R.; Calatayud, S.; Ladurner, P.; Schlick-Steiner, B.; et al. Metallomics reveal a persisting impact of cadmium on the evolution of metal-selective metallothioneins. Metallomics 2020. accepted.

20. Dallinger, R.; Berger, B. Function of metallothioneins in terrestrial gastropods. Sci. Total Environ. 1993, 134, 607-615. [CrossRef]

21. Berger, B.; Dallinger, R.; Gehrig, P.; Hunziker, P.E. Primary structure of a copper-binding metallothionein from mantle tissue of the terrestrial gastropod Helix pomatia L. J. Biochem. 1997, 328, 219-224. [CrossRef]

22. Pedrini-Martha, V.; Schnegg, R.; Baurand, P.E.; de Vaufleury, A.; Dallinger, R. The physiological role and toxicological significance of the non-metal-selective cadmium/copper-metallothionein isoform differ between embryonic and adult helicid snails. Comp. Biochem. Physiol. Part C Toxicol. Pharm. 2017, 199, 38-47. [CrossRef]

23. Dallinger, R.; Berger, B.; Hunziker, P.; Kägi, H.R.J. Metallothionein in snail Cd and Cu metabolism. Nature 1997, 143, 831-833. [CrossRef] [PubMed]

24. Pérez-Rafael, S.; Monteiro, F.; Dallinger, R.; Atrian, S.; Palacios, Ò.; Capdevila, M. Cantareus aspersus metallothionein metal binding abilities: The unspecific $\mathrm{CaCd} / \mathrm{CuMT}$ isoform provides hints about the metal preference determinants in metallothioneins. Biochim. Biophys. Acta Proteins Proteom. 2014, 1844, 1694-1707. [CrossRef] [PubMed]

25. Beil, A.; Jurt, S.; Walser, R.; Schönhut, T.; Güntert, P.; Palacios, Ò.; Atrian, S.; Capdevila, M.; Dallinger, R.; Zerbe, O. The Solution Structure and Dynamics of Cd-Metallothionein from Helix pomatia Reveal Optimization for Binding Cd over Zn. Biochemistry 2019, 58, 4570-4581. [CrossRef] [PubMed]

26. Baumann, C.; Beil, A.; Jurt, S.; Niederwanger, M.; Palacios, O.; Capdevila, M.; Atrian, S.; Dallinger, R.; Zerbe, O. Structural Adaptation of a Protein to Increased Metal Stress: NMR Structure of a Marine Snail Metallothionein with an Additional Domain. Angew. Chem. Int. Ed. 2017, 56, 4617-4622. [CrossRef]

27. Schmielau, L.; Dvorak, M.; Niederwanger, M.; Dobieszewski, N.; Pedrini-Martha, V.; Ladurner, P.; Pedregal, J.R.G.; Maréchal, J.D.; Dallinger, R. Differential response to Cadmium exposure by expression of a two and a three-domain metallothionein isoform in the land winkle Pomatias elegans: Valuating the marine heritage of a land snail. Sci. Total Environ. 2019, 648, 561-571. [CrossRef]

28. Palacios, Ò.; Jiménez-Martí, E.; Niederwanger, M.; Gil-Moreno, S.; Zerbe, O.; Atrian, S.; Dallinger, R.; Capdevila, M. Analysis of metal-binding features of the wild type and two domain-truncated mutant variants of littorina littorea metallothionein reveals its cd-specific character. Int. J. Mol. Sci. 2017, 18, 1452. [CrossRef]

29. Maroni, G.; Wise, J.; Young, J.E.; Otto, E. Metallothionein Gene Duplications and Metal Tolerance in Natural Populations of Drosophila Melanogaster. Genetics 1987, 117, 739-744.

30. Tóth, G.; Hermann, T.; Da Silva, M.R.; Montanarella, L. Heavy metals in agricultural soils of the European Union with implications for food safety. Environ. Int. 2016, 88, 299-309. [CrossRef]

31. Trzcińska, M.; Pawlik-Skowrońska, B. Soil algal communities inhabiting zinc and lead mine spoils. J. Appl. Phycol. 2008, 20, 341-348. [CrossRef]

32. Coughtrey, P.; Jones, C.; Martin, M.; Shales, S. Litter Accumulation in Woodlands Contaminated. Oecologia 1979, 39, 51-60. [CrossRef] 
33. Lepp, N.W.; Madejón, P. Cadmium and zinc in vegetation and litter of a voluntary woodland that has developed on contaminated sediment-derived soil. Proc. J. Environ. Qual. 2007, 36, 1123-1131. [CrossRef]

34. Dallinger, R. Strategies of metal detoxification in terrestrial invertebrates. In Ecotoxicology of Metals in Invertebrates; Dallinger, R., Rainbow, P.S., Eds.; Lewis Publisher: Boca Rota, FL, USA, 1993; pp. 245-289. ISBN 9780873717342.

35. Regoli, F.; Gorbi, S.; Fattorini, D.; Tedesco, S.; Notti, A.; Machella, N.; Bocchetti, R.; Benedetti, M.; Piva, F. Use of the land snail Helix aspersa sentinel organism for monitoring ecotoxicologic effects of urban pollution: An integrated approach. Environ. Health Perspect. 2006, 114, 63-69. [CrossRef] [PubMed]

36. Dallinger, R.; Berger, B.; Triebskorn-Köhler, R.; Köhler, A.H. 4 Soil Biology and Ecotoxicology. In The Biology of Terrestrial Mollsucs; Barker, G.M., Ed.; CABI Publishing: Oxon, UK, 2001; pp. 489-525.

37. De Vaufleury, A.G.; Bispo, A. Methods for toxicity assessment of contaminated soil by oral or dermal uptake in land snails. 1. Sublethal effects on growth. Environ. Sci. Technol. 2000, 34, 1865-1870. [CrossRef]

38. Coeurdassier, M.; Gomot-De Vaufleury, A.; Lovy, C.; Badot, P.-M. Is the cadmium uptake from soil important in bioaccumulation and toxic effects for snails? Ecotoxicol. Environ. Saf. 2002, 53, 425-431. [CrossRef]

39. Laskowski, R.; Hopkin, S.P. Effect of $\mathrm{Zn}, \mathrm{Cu}, \mathrm{Pb}$, and $\mathrm{Cd}$ on Fitness in Snails (Helix aspersa). Ecotoxicol. Environ. Saf. 1996, 34, 59-69. [CrossRef] [PubMed]

40. Notten, M.J.M.; Oosthoek, A.J.P.; Rozema, J.; Aerts, R. Heavy metal pollution affects consumption and reproduction of the landsnail Cepaea nemoralis fed on naturally polluted Urtica dioica leaves. Ecotoxicology 2006, 15, 295-304. [CrossRef] [PubMed]

41. El-Gendy, K.S.; Radwan, M.A.; Gad, A.F. Feeding and growth responses of the snail theba pisana to dietary metal exposure. Arch. Environ. Contam. Toxicol. 2011, 60, 272-280. [CrossRef]

42. Schüder, I.; Port, G.; Bennison, J. The behavioural response of slugs and snails to novel molluscicides, irritants and repellents. Pest Manag. Sci. 2004, 60, 1171-1177. [CrossRef]

43. Lefcort, H.; Abbott, D.P.; Cleary, D.A.; Howell, E.; Keller, N.C.; Smith, M.M. Aquatic Snails from Mining Sites Have Evolved to Detect and Avoid Heavy Metals. Arch. Environ. Contam. Toxicol. 2004, 46, 478-484. [CrossRef]

44. Cain, D.J.; Croteau, M.N.; Fuller, C.C.; Ringwood, A.H. Dietary Uptake of Cu Sorbed to Hydrous Iron Oxide is Linked to Cellular Toxicity and Feeding Inhibition in a Benthic Grazer. Environ. Sci. Technol. 2016, 50, 1552-1560. [CrossRef]

45. Moore, M.N.; Shaw, J.P.; Ferrar Adams, D.R.; Viarengo, A. Anti-oxidative cellular protection effect of fasting-induced autophagy as a mechanism for hormesis. Mar. Environ. Res. 2015, 107, 35-44. [CrossRef] [PubMed]

46. Moleirinho, A.; Carneiro, J.; Matthiesen, R.; Silva, R.M.; Amorim, A.; Azevedo, L. Gains, losses and changes of function after gene duplication: Study of the metallothionein family. PLoS ONE 2011, 6, e18487. [CrossRef] [PubMed]

47. Calatayud, S.; Garcia-Risco, M.; Rojas, N.S.; Espinosa-Sánchez, L.; Artime, S.; Palacios, O.; Cañestro, C.; Albalat, R. Metallothioneins of the urochordate Oikopleura dioica have Cys-rich tandem repeats, large size and cadmium-binding preference. Metallomics 2018, 10, 1585-1594. [CrossRef] [PubMed]

48. Niederwanger, M.; Dvorak, M.; Schnegg, R.; Pedrini-Martha, V.; Bacher, K.; Bidoli, M.; Dallinger, R. Challenging the Metallothionein (MT) gene of Biomphalaria glabrata: Unexpected response patterns due to cadmium exposure and temperature stress. Int. J. Mol. Sci. 2017, 18, 1747. [CrossRef] [PubMed]

49. Iturbe-Espinoza, P.; Gil-Moreno, S.; Lin, W.; Calatayud, S.; Palacios, Ò.; Capdevila, M.; Atrian, S. The fungus Tremella mesenteric encodes the longest metallothionein currently known: Gene, protein and metal binding characterization. PLoS ONE 2016, 11, e0148651. [CrossRef] [PubMed]

50. Jenny, M.J.; Ringwood, A.H.; Schey, K.; Warr, G.W.; Chapman, R.W. Diversity of metallothioneins in the American oyster, Crassostrea virginica, revealed by transcriptomic and proteomic approaches. Eur. J. Biochem. 2004, 271, 1702-1712. [CrossRef]

51. Piccinni, E.; Bertaggia, D.; Santovito, G.; Miceli, C.; Kraev, A. Cadmium metallothionein gene of Tetrahymena pyriformis k. Gene 1999, 234, 51-59. [CrossRef]

52. Piccinni, E.; Irato, P.; Coppellotti, O.; Guidolin, L. Biochemical and ultrastructural data on Tetrahymena pyriformis treated with copper and cadmium. J. Cell Sci. 1987, 88, 283-293.

53. Hung, M.S.; Lin, Y.C.; Mao, J.H.; Kim, I.J.; Xu, Z.; Yang, C.T.; Jablons, D.M.; You, L. Functional polymorphism of the CK2 $\alpha$ intronless gene plays oncogenic roles in lung cancer. PLoS ONE 2010, 5, e11418. [CrossRef] 
54. Hunt, C.; Calderwood, S. Characterization and sequence of a mouse hsp70 gene and its expression in mouse cell lines. Gene 1990, 87, 199-204. [CrossRef]

55. Grzybowska, E.A. Human intronless genes: Functional groups, associated diseases, evolution, and mRNA processing in absence of splicing. Biochem. Biophys. Res. Commun. 2012, 424, 1-6. [CrossRef] [PubMed]

56. Louhichi, A.; Fourati, A.; Rebaï, A. IGD: A resource for intronless genes in the human genome. Gene 2011, 488, 35-40. [CrossRef] [PubMed]

57. Shabalina, S.A.; Ogurtsov, A.Y.; Spiridonov, A.N.; Novichkov, P.S.; Spiridonov, N.A.; Koonin, E.V. Distinct patterns of expression and evolution of intronless and intron-containing mammalian genes. Mol. Biol. Evol. 2010, 27, 1745-1749. [CrossRef] [PubMed]

58. Otto, E.; Young, J.E.; Maroni, G. Structure and expression of a tandem duplication of the Drosophila metallothionein gene (gene amplification/cadmium resistance/Min gene). Genetics 1986, 83, 6025-6029.

59. Richardson, S.R.; Salvador-Palomeque, C.; Faulkner, G.J. Diversity through duplication: Whole-genome sequencing reveals novel gene retrocopies in the human population. BioEssays 2014, 36, 475-481. [CrossRef] [PubMed]

60. Karin, M.; Richards, R.I. Human metallothionein genes-primary structure of the metallothionein-II gene and a related processed gene. Nature 1982, 299, 797-802. [CrossRef]

61. Poliseno, L.; Salmena, L.; Zhang, J.; Carver, B.; Haveman, W.J.; Pandolfi, P.P. A coding-independent function of gene and pseudogene mRNAs regulates tumour biology. Nature 2010, 465, 1033-1038. [CrossRef]

62. Casola, C.; Betrán, E. The genomic impact of gene retrocopies: What have we learned from comparative genomics, population genomics, and transcriptomic analyses? Genome Biol. Evol. 2017, 9, 1351-1373. [CrossRef]

63. Roy, S.W.; Gilbert, W. Rates of intron loss and gain: Implications for early eukaryotic evolution. PNAS 2005, 102, 5773-5778. [CrossRef]

64. Loh, Y.H.; Brenner, S.; Venkatesh, B. Investigation of loss and gain of introns in the compact genomes of pufferfishes (Fugu and Tetraodon). Mol. Biol. Evol. 2008, 25, 526-535. [CrossRef]

65. Robertson, G.; Schein, J.; Chiu, R.; Corbett, R.; Field, M.; Jackman, S.D.; Mungall, K.; Lee, S.; Okada, H.M.; Qian, J.Q.; et al. De novo assembly and analysis of RNA-seq data. Nat. Methods 2010, 7, 909-912. [CrossRef] [PubMed]

66. Cocquet, J.; Chong, A.; Zhang, G.; Veitia, R.A. Reverse transcriptase template switching and false alternative transcripts. Genomics 2006, 88, 127-131. [CrossRef] [PubMed]

67. Houseley, J.; Tollervey, D. Apparent non-canonical trans-splicing is generated by reverse transcriptase in vitro. PLoS ONE 2010, 5, e12271. [CrossRef] [PubMed]

68. Geiszt, M.; Lekstrom, K.; Leto, T.L. Analysis of mRNA transcripts from the NAD(P)H oxidase 1 (Nox1) gene: Evidence against production of the NADPH oxidase homolog-1 short (NOH-1s) transcript variant. J. Biol. Chem. 2004, 279, 51661-51668. [CrossRef] [PubMed]

69. Gao, M.; Liu, Y.; Chen, Y.; Yin, C.; Chen, J.J.; Liu, S. MiR-214 protects erythroid cells against oxidative stress by targeting ATF4 and EZH2. Free Radic. Biol. Med. 2016, 92, 39-49. [CrossRef] [PubMed]

70. Tang, Y.; Quail, M.A.; Artymiuk, P.J.; Guest, J.R.; Green, J. Escherichia coli aconitases and oxidative stress: Post-transcriptional regulation of sodA expression. Microbiology 2002, 148, 1027-1037. [CrossRef]

71. Koritzinsky, M.; Seigneuric, R.; Magagnin, M.G.; Van Den Beucken, T.; Lambin, P.; Wouters, B.G. The hypoxic proteome is influenced by gene-specific changes in mRNA translation. Proc. Radiother. Oncol. 2005, 76, 177-186. [CrossRef]

72. Dallinger, R.; Chabicovsky, M.; Berger, B. Isoform-specific quantification of metallothionein in the terrestrial gastropod Helix pomatia. I. Molecular, biochemical, and methodical background. Environ. Toxicol. Chem. 2004, 23, 890-901. [CrossRef]

73. Banni, M.; Messaoudi, I.; Said, L.; El Heni, J.; Kerkeni, A.; Said, K. Metallothionein gene expression in liver of rats exposed to cadmium and supplemented with zinc and selenium. Arch. Environ. Contam. Toxicol. 2010, 59, 513-519. [CrossRef]

74. Bourdineaud, J.P.; Baudrimont, M.; Gonzalez, P.; Moreau, J.L. Challenging the model for induction of metallothionein gene expression. Biochimie 2006, 88, 1787-1792. [CrossRef]

75. Cheung, A.P.L.; Lam, T.H.J.; Chan, K.M. Regulation of Tilapia metallothionein gene expression by heavy metal ions. Proc. Mar. Environ. Res. 2004, 58, 389-394. [CrossRef] [PubMed] 
76. Kim, J.H.; Rhee, J.S.; Dahms, H.U.; Lee, Y.M.; Han, K.N.; Lee, J.S. The yellow catfish, Pelteobagrus fulvidraco (Siluriformes) metallothionein cDNA: Molecular cloning and transcript expression level in response to exposure to the heavy metals $\mathrm{Cd}, \mathrm{Cu}$, and Zn. Fish Physiol. Biochem. 2012, 38, 1331-1342. [CrossRef]

77. Brulle, F.; Mitta, G.; Leroux, R.; Lemière, S.; Leprêtre, A.; Vandenbulcke, F. The strong induction of metallothionein gene following cadmium exposure transiently affects the expression of many genes in Eisenia fetida: A trade-off mechanism? Comp. Biochem. Physiol. C Toxicol. Pharm. 2007, 144, 334-341. [CrossRef]

78. Palacios, Ò.; Espart, A.; Espín, J.; Ding, C.; Thiele, D.J.; Atrian, S.; Capdevila, M. Full characterization of the $\mathrm{Cu}_{-}, \mathrm{Zn}-$, and $\mathrm{Cd}$-binding properties of CnMT1 and CnMT2, two metallothioneins of the pathogenic fungus Cryptococcus neoformans acting as virulence factors. Proc. Met. 2014, 6, 279-291. [CrossRef] [PubMed]

79. Niederwanger, M.; Calatayud, S.; Zerbe, O.; Atrian, S.; Albalat, R.; Capdevila, M.; Palacios, Ò.; Dallinger, R. Biomphalaria glabrata metallothionein: Lacking metal specificity of the protein and missing gene upregulation suggest metal sequestration by exchange instead of through selective binding. Int. J. Mol. Sci. 2017, 18, 1457. [CrossRef]

80. Zangger, K.; Öz, G.; Otvos, J.D.; Armitage, I.M. Three-Dimensional Solution Structure of Mouse [Cd7]-Metallothionein-1 by Homonuclear and Heteronuclear NMR Spectroscopy; Cambridge University Press: Cambridge, UK, 1999; p. 8.

81. Palacios, Ò.; Pérez-Rafael, S.; Pagani, A.; Dallinger, R.; Atrian, S.; Capdevila, M. Cognate and noncognate metal ion coordination in metal-specific metallothioneins: The Helix pomatia system as a model. J. Biol. Inorg. Chem. 2014, 19, 923-935. [CrossRef] [PubMed]

82. Pérez-Rafael, S.; Pagani, A.; Palacios, Ò.; Dallinger, R.; Capdevila, M.; Atrian, S. The role of histidine in a copper-specific metallothionein. Z. Fur Anorg. Und Allg. Chem. 2013, 639, 1356-1360. [CrossRef]

83. Palacios, O.; Pagani, A.; Pérez-Rafael, S.; Egg, M.; Höckner, M.; Brandstätter, A.; Capdevila, M.; Atrian, S.; Dallinger, R. Shaping mechanisms of metal specificity in a family of metazoan metallothioneins: Evolutionary differentiation of mollusc metallothioneins. BMC Biol. 2011, 9, 4. [CrossRef]

84. Höckner, M.; Stefanon, K.; De Vaufleury, A.; Monteiro, F.; Pérez-Rafael, S.; Palacios, Ò.; Capdevila, M.; Atrian, S.; Dallinger, R. Physiological relevance and contribution to metal balance of specific and non-specific Metallothionein isoforms in the garden snail, Cantareus Aspersus. Biometals 2011, 24, 1079-1092. [CrossRef]

85. Ding, C.; Festa, R.A.; Chen, Y.L.; Espart, A.; Palacios, Ò.; Espín, J.; Capdevila, M.; Atrian, S.; Heitman, J.; Thiele, D.J. Cryptococcus neoformans copper detoxification machinery is critical for fungal virulence. Cell Host Microbe 2013, 13, 265-276. [CrossRef]

86. Dallinger, R. Gastropod Metallothioneins in Evolution: New Rules for an Old Protein Family; Hobmayer, B., Micura, R., Striessnig, J., Eds.; CMBI: Innsbruck, Austria, 2018; pp. 24-25.

87. Pérez, L.M.; Fittipaldi, M.; Adrados, B.; Morató, J.; Codony, F. Error estimation in environmental DNA targets quantification due to PCR efficiencies differences between real samples and standards. Folia Microbiol. 2013, 58, 657-662. [CrossRef] [PubMed]

(C) 2020 by the authors. Licensee MDPI, Basel, Switzerland. This article is an open access article distributed under the terms and conditions of the Creative Commons Attribution (CC BY) license (http://creativecommons.org/licenses/by/4.0/). 